\title{
The Pothole Hydrology-Linked Systems Simulator (PHyLiSS)_Development and Application of a Systems Model for Prairie-Pothole Wetlands
}

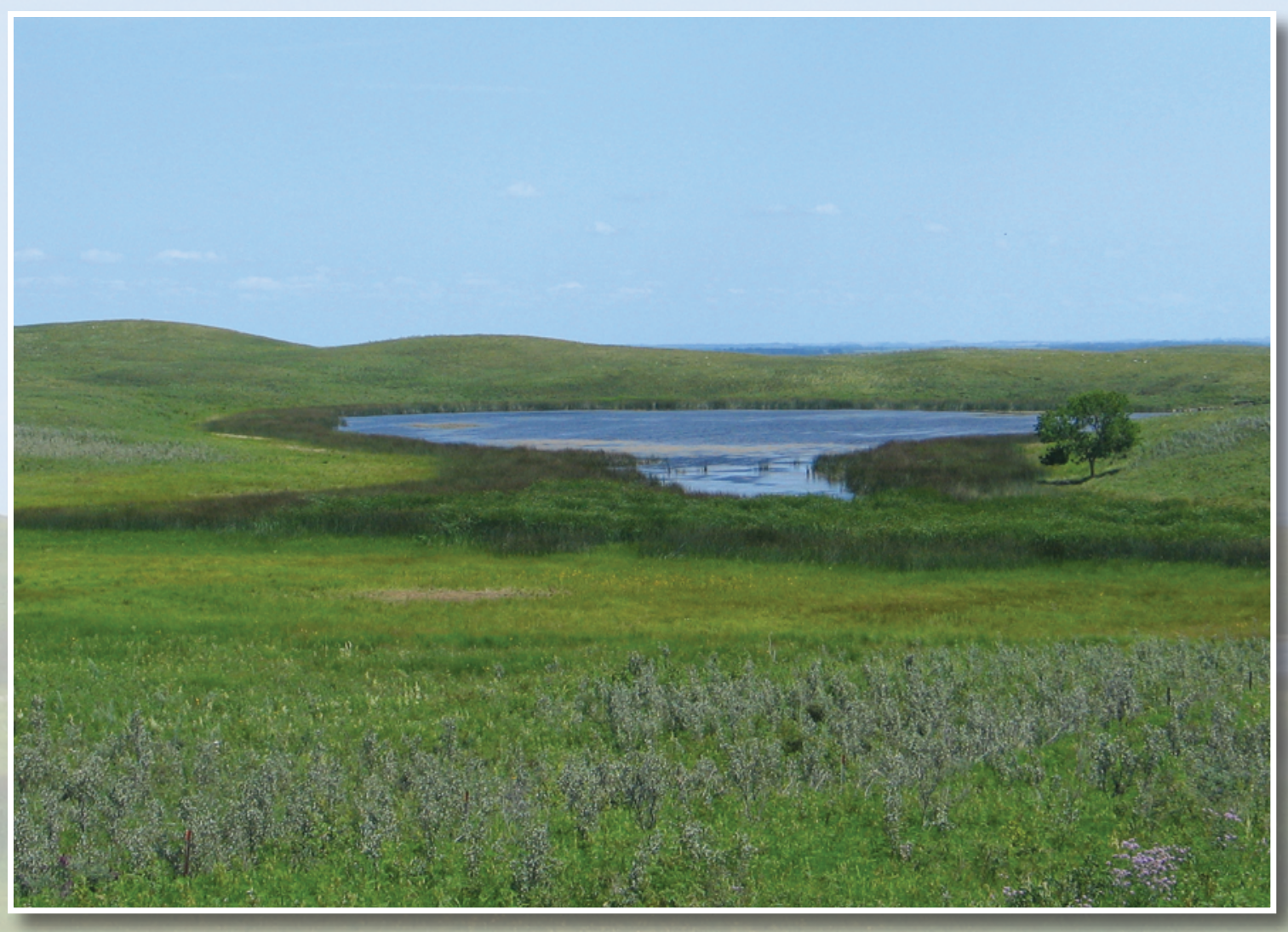

Open File Report 2018-1165 
Cover: A semipermanently ponded prairie-pothole wetland in Stutsman County, North Dakota, August 3, 2004. Photograph by David Mushet, U.S. Geological Survey. 


\section{The Pothole Hydrology-Linked Systems Simulator (PHyLiSS)—Development and Application of a Systems Model for Prairie- Pothole Wetlands}

By Owen P. McKenna, David M. Mushet, Eric J. Scherff, Kyle I. McLean, and Christopher T. Mills

Open File Report 2018-1165 


\title{
U.S. Department of the Interior \\ RYAN K. ZINKE, Secretary
}

\author{
U.S. Geological Survey \\ James F. Reilly II, Director
}

U.S. Geological Survey, Reston, Virginia: 2018

For more information on the USGS - the Federal source for science about the Earth, its natural and living resources, natural hazards, and the environment-visit https://www.usgs.gov or call 1-888-ASK-USGS.

For an overview of USGS information products, including maps, imagery, and publications,

visit https://store.usgs.gov.

Any use of trade, firm, or product names is for descriptive purposes only and does not imply endorsement by the U.S. Government.

Although this information product, for the most part, is in the public domain, it also may contain copyrighted materials as noted in the text. Permission to reproduce copyrighted items must be secured from the copyright owner.

Suggested citation:

McKenna, O.P., Mushet, D.M., Scherff, E.J., McLean, K.I., and Mills, C.T., 2018, The Pothole Hydrology-Linked Systems Simulator (PHyLiSS) —Development and application of a systems model for prairie-pothole wetlands: U.S. Geological Survey Report 2018-1165, 21 p., https://doi.org/10.3133/ofr20181165.

ISSN 0196-1497 (print)

ISSN 2331-1258 (online)

ISBN 978-1-4113-4266-8 


\section{Acknowledgments}

Development of the Pothole Hydrology-Linked Systems Simulator model would not have been possible but for the pioneering work of George A. Swanson (deceased), Thomas C. Winter (deceased), Donald O. Rosenberry, and James W. LaBaugh who worked together in the late 1970s and early 1980s to establish the surface-water, groundwater, and water-chemistry monitoring network at the Cottonwood Lake Study Area. We also are greatly indebted to Ned H. Euliss, Jr., who expanded the monitoring effort in 1992 to include detailed quantifications of the water-bird, amphibian, aquatic-macroinvertebrate, and plant communities at the site. We also thank Richard D. Nelson for ensuring that water chemistry sampling continued at the site during a period (1992-2002) when previous sources of funding became unavailable. We thank the many technicians, biologists, ecologists, student contractors, and volunteers who have worked tirelessly over the years to collect, enter, and maintain the rich data resources now available from the study site. We especially thank Bruce Hanson, Richard Hegvik, Stephen Lane, and Matthew Solensky for their efforts leading field crews and supervising laboratory processing of collected samples. Initial funding supporting the development of a systems model for prairie-pothole wetlands was provided by the Conservation Effects Assessment Project of the U.S. Department of Agriculture's Natural Resources Conservation Service. Long-term monitoring data from Cottonwood Lake Study Area wetlands are publicly available through the Missouri Coteau Wetland Ecosystem Observatory (https://www.sciencebase.gov/catalog/ item/52f0ffd9e4b0f941aa181fc6) and maintained through funding received from the Research and Development component of the U.S. Geological Survey Land Change Science Program. 



\section{Contents}

Acknowledgments ……...................................................................................................................

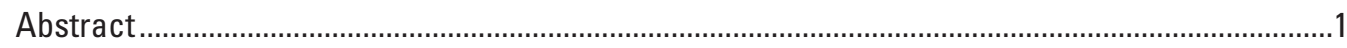

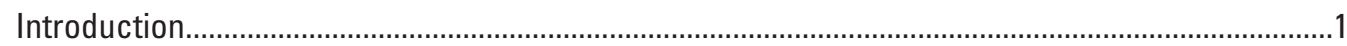

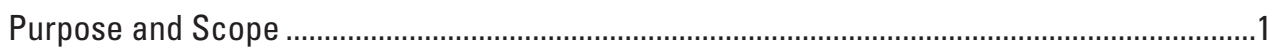

The Prairie Pothole Region .....................................................................................................

Climate and Land-Use Change in the Prairie Pothole Region ...................................................

Wetland Modeling Efforts in the Prairie Pothole Region ........................................................

Pothole Hydrology-Linked Systems Simulator (PHyLiSS) Model Documentation ...............................

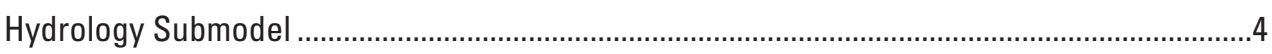

Precipitation, Runoff, and Snowmelt...........................................................................

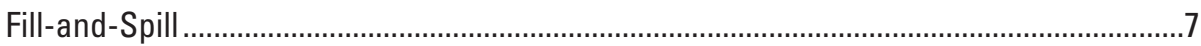

Evaporation and Transpiration Losses ...........................................................................

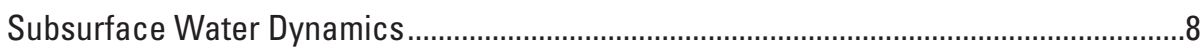

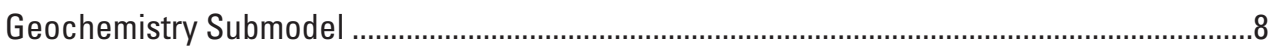

Subsurface Water-Salt Dynamics..................................................................................

Soil-Salt Dynamics .......................................................................................................

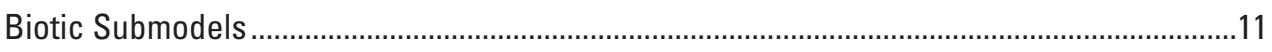

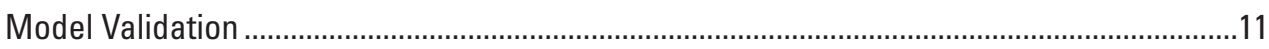

Hydrology Submodel Validation ..............................................................................11

Salinity Submodel Validation ......................................................................................13

Using the Pothole Hydrology-Linked Systems Simulator (PHyLiSS) Model ....................................13

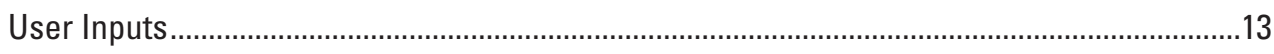

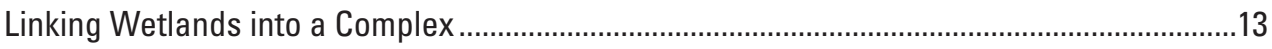

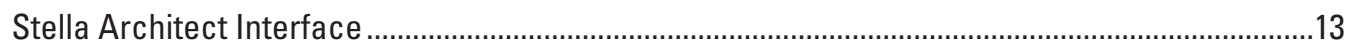

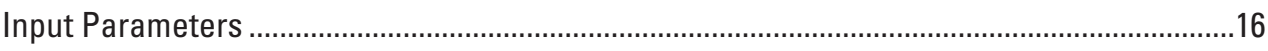

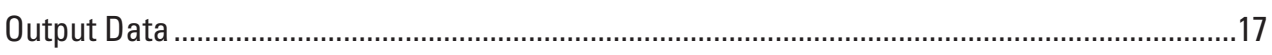

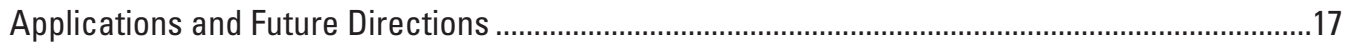

Continued Model Development................................................................................................

Geochemical Mechanisms .............................................................................................17

Expansion Throughout the Prairie Pothole Region ...........................................................17

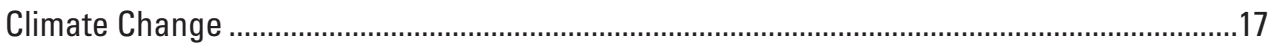

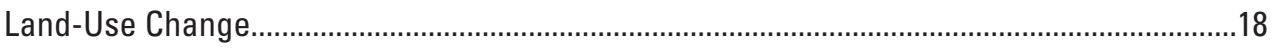

Integrated Landscape Modeling Partnership ................................................................. 18

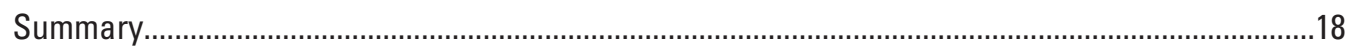

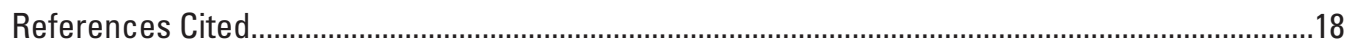




\section{Figures}

1. Map showing the North American Prairie Pothole Region.

2. Diagram showing a hydrogeochemical conceptual model for prairie-pothole wetlands

3. Diagram showing a Stella schematic of the Pothole Hydrology-Linked Systems Simulator model

4. Map showing prairie-pothole wetlands in the Cottonwood Lake study area, Stutsman County, North Dakota

5. Graphs showing observed versus modeled water levels for six wetlands in the Cottonwood Lake study area, Stutsman County, North Dakota.

6. Graphs showing observed versus modeled total dissolved solids in wetlands P1, P6, and P7 in the Cottonwood Lake study area, Stutsman County, North Dakota ...........14

7. Screenshot showing the Stella Architect user interface for the Pothole Hydrology-Linked Systems Simulator model

\section{Tables}

1. Soil Conservation Service Runoff Curve Numbers by land cover .......................................

2. Annual groundwater recharge and discharge estimates .................................................

3. Cottonwood Lake study area validation wetland characteristics.....................................11

4. Regression analysis for modeled versus observed wetland stage validation.................13

5. Regression analysis for modeled versus observed wetland total dissolved solids validation.

6. User inputs needed to run the Pothole Hydrology-Linked Systems Simulator model for a given prairie-pothole wetland

7. Models developed to estimate wetland volume and upland-zone area by physiographic region in the Prairie Pothole Region 


\section{Conversion Factors}

International System of Units to U.S. customary units

\begin{tabular}{lcl}
\hline \multicolumn{1}{c}{ Multiply } & By & \multicolumn{1}{c}{ To obtain } \\
\hline meter $(\mathrm{m})$ & Length & yard (yd) \\
\hline \multicolumn{2}{c}{ Area } & \\
\hline square meter $\left(\mathrm{m}^{2}\right)$ & 0.0002471 & acre \\
hectare $(\mathrm{ha})$ & 2.471 & acre \\
square kilometer $\left(\mathrm{km}^{2}\right)$ & 0.3861 & square mile $\left(\mathrm{mi}^{2}\right)$ \\
\hline & Volume & \\
\hline cubic meter $\left(\mathrm{m}^{3}\right)$ & 264.2 & gallon $(\mathrm{gal})$ \\
\hline & Flow rate & inch per year $(\mathrm{in} / \mathrm{yr})$ \\
\hline millimeter per year $(\mathrm{mm} / \mathrm{yr})$ & 0.03937 & pound avoirdupois $(\mathrm{lb})$ \\
\hline
\end{tabular}

Temperature in degrees Celsius $\left({ }^{\circ} \mathrm{C}\right)$ may be converted to degrees Fahrenheit $\left({ }^{\circ} \mathrm{F}\right)$ as ${ }^{\circ} \mathrm{F}=\left(1.8 \times{ }^{\circ} \mathrm{C}\right)+32$.

\section{Datum}

Vertical coordinate information is referenced to the North American Vertical Datum of 1988 (NAVD 88).

\section{Supplemental Information}

Note to USGS users: Use of hectare (ha) as an alternative name for square hectometer ( $\mathrm{hm}^{2}$ ) is restricted to the measurement of small land or water areas.

Use of microsiemens per centimeter $(\mu \mathrm{S} / \mathrm{cm})$ is restricted to the measurement of electrical conductivity, which is a common measurement of salinity.

\section{Abbreviations}

PHDI Palmer Hydrological Drought Index

PHyLiSS Pothole Hydrology-Linked Systems Simulator [model]

TDS total dissolved solids

WETSIM Wetland Simulator [model]

WLS WETLANDSCAPE [model] 



\title{
The Pothole Hydrology-Linked Systems Simulator (PHyLiSS) - Development and Application of a Systems Model for Prairie-Pothole Wetlands
}

\author{
By Owen P. McKenna, ${ }^{1}$ David M. Mushet, ${ }^{1}$ Eric J. Scherff, ${ }^{2}$ Kyle I. McLean, ${ }^{1}$ and Christopher T. Mills ${ }^{1}$
}

\section{Abstract}

The North American Prairie Pothole Region covers about 770,000 square kilometers of the United States and Canada (including parts of 5 States and 3 provinces: North Dakota, South Dakota, Montana, Minnesota, Iowa, Saskatchewan, Manitoba, and Alberta). The Laurentide Ice Sheet shaped the landscape of the region about 12,000 to 14,000 years ago. The retreat of the ice sheet left behind low-permeability glacial till and a landscape dotted with millions of depressions known today as prairie potholes. The wetlands that subsequently formed in these depressions, prairie-pothole wetlands, provide critical migratory-bird habitat and support dynamic aquatic communities. Extensive grasslands and productive agricultural systems surround these wetland ecosystems. In prairie-pothole wetlands, the compositions of plant, invertebrate, and vertebrate communities are highly dependent on hydrogeochemical conditions. Regional climate shifts between wet and dry periods affect the length of time that wetlands contain ponded surface water and the chemistry of that ponded water. Landuse change can exacerbate or reduce the effects of climate on wetland hydrology and water chemistry.

A mechanistic understanding of the relation among climate, land use, hydrology, chemistry, and biota in prairiepothole wetlands is needed to better understand the complex, and often interacting, effects of climate and land use on prairie-pothole wetland systems and to facilitate climate and land-use change adaptation efforts. The Pothole HydrologyLinked Systems Simulator (PHyLiSS) model was developed to address this need. The model simulates water-surface elevation dynamics in prairie-pothole wetlands and quantifies changes in salinity. The PHyLiSS model is unique among other wetland models because it accommodates differing sizes and morphometries of wetland basins, is not dependent on $a$ priori designations of wetland class, and allows for functional changes associated with dynamic shifts in ecohydrological states. The PHyLiSS model also has the capability to simulate wetland salinity, and potential future iterations will also simulate the effects of changing hydrology and geochemical conditions on biota. This report documents the development of the hydrological and geochemical components of the PHyLiSS model and provides example applications.

\section{Introduction}

Prairie-pothole wetland ecosystems provide critical migratory-bird habitat and support dynamic aquatic communities. These wetlands are in the North American Prairie Pothole Region (fig. 1), which is a mid-continental region that has a very dynamic climate and is undergoing land-use change pressures. To better understand how prairie-pothole wetlands currently function and may function in the future, we have developed the Pothole Hydrology-Linked Systems Simulator (PHyLiSS).

\section{Purpose and Scope}

We developed PHyLiSS as a tool for accurately simulating prairie-pothole wetland hydrology and geochemistry using site-specific meteorological, land-use, and morphological information. This development of PHyLiSS was motivated by the need for an open-access model that can be used to inform land management decisions regarding prairiepothole wetlands. Here, we document the development of the PHyLiSS model and provide theoretical background and technical guidelines for model users. As future iterations of the PHyLiSS model are developed and released, we plan to update the information provided within this report.

\footnotetext{
${ }^{1}$ U.S. Geological Survey.
} 

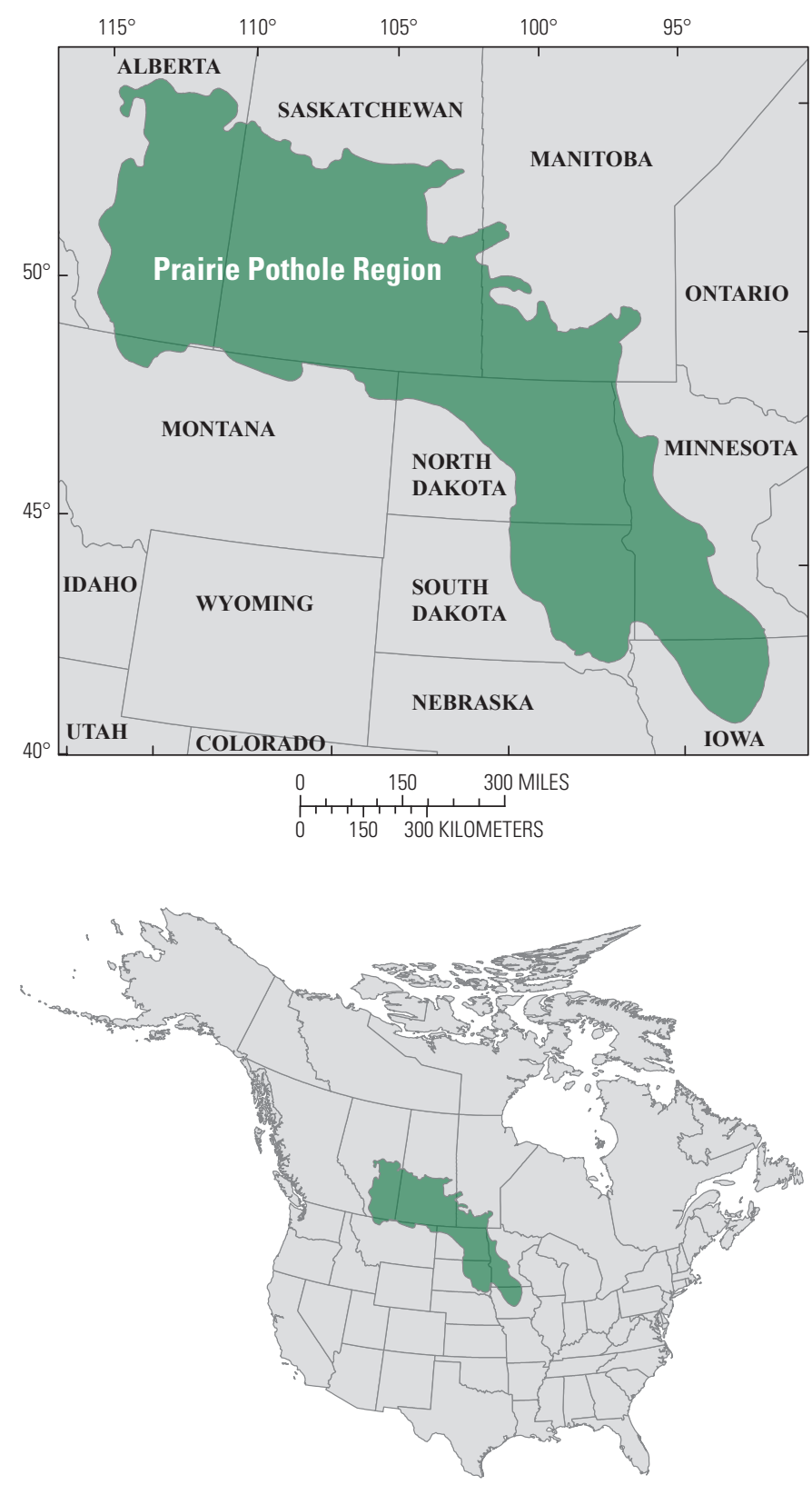

Figure 1. North American Prairie Pothole Region.

\section{The Prairie Pothole Region}

The North American Prairie Pothole Region covers about 770,000 square kilometers $\left(\mathrm{km}^{2}\right)$ of the United States and Canada (fig. 1; Smith and others, 1964). The advance and retreat of the Laurentide Ice Sheet (Dyke and Prest, 1987) resulted in the Prairie Pothole Region being covered with low-permeability glacial till and millions of closed-catchment depressions (Goldhaber and others, 2014) that are commonly referred to as prairie potholes. The wetlands that formed in these depressions (hereafter referred to as "prairie-pothole wetlands") provide critical migratory-bird breeding habitat from which between 50 and 80 percent of the North American migratory-duck population is produced each year (Batt and others, 1989). About the top 10 meters (m) of soils of the Prairie Pothole Region consist of weathered glacial till (Goldhaber and others, 2014). Weathering processes such as the oxidation of pyrite $\left(\mathrm{FeS}_{2}\right)$ provide a large supply of solutes that can be transferred to and from ponded wetland water (Goldhaber and others, 2016). Transpiration of water by emergent wetland plant species such as Typha spp. (cattail) concentrates salts into shallow, subsurface "salt rings" around wetland ponds (Winter and Rosenberry, 1995; Nachshon and others, 2013; Levy and others, 2018b).

The permanence and salinity of ponded water in prairiepothole wetlands varies topographically along the landscape in relation to groundwater (Winter, 2003). Wetlands high in the local topography have ponds that typically dry annually and lose solutes to groundwater recharge. This net export of salts keeps their waters fresh. Wetlands lower on the landscape have ponds that are more permanent and accumulate solutes from discharging groundwater or via surface flows from other wetlands. Water loss from wetlands in local topographic lows is through evapotranspiration, so salts accumulate in these systems and they become highly saline (LaBaugh and others, 2018). Hydrogeochemical variability among closely situated wetlands contributes to heterogeneity across the Prairie Pothole Region landscape and forms distinct habitats that support a wide variety of plant, invertebrate, and vertebrate communities (Mushet and others, 2015).

The climate of the Prairie Pothole Region is continental with a large degree of spatial and temporal variability (Rosenberry, 2003; Mushet, 2016). Annual precipitation displays patterns of high variability on an interannual scale (Hayashi and others, 2016), as well as decadal oscillations between wet and dry modes (Winter and Rosenberry, 1998) that strongly affect the hydrological status of the region's wetlands (McKenna and others, 2017). Much of the United States' part of the Prairie Pothole Region has been in a "wet period" since 1993 (McKenna and others, 2017). More recently, these wet conditions have extended north into Canada (Hayashi and others, 2016). These increasingly wet conditions across the Prairie Pothole Region can affect runoff generated by snowmelt and high-intensity rainstorms (Shook and Pomeroy, 2012; Dumanski and others, 2015). Additionally, the wet conditions affecting the Prairie Pothole Region coincide with air temperatures that are increasing by about 0.14 degree Celsius $\left({ }^{\circ} \mathrm{C}\right)$ per decade (Todhunter and Fietzek-DeVries, 2016). Overall, the current 25 -year sustained wet period has been greater in magnitude and has persisted longer than any wet period in the Prairie Pothole Region during the last century (McKenna and others, 2017) and perhaps the last 500 years (Winter and Rosenberry, 1998). This climate shift has distinctly altered the surface-runoff dynamics (Ryberg and others, 2014) of aquatic and terrestrial systems of the southern Prairie Pothole Region (McKenna and others, 2017) and is predicted to continue (Johnson and Poiani, 2016). 


\section{Climate and Land-Use Change in the Prairie Pothole Region}

Prairie-pothole-wetland trophic structures are strongly affected by pond permanence and water salinity (McLean and others, 2016a). The most immediate effects of a wetter climate on wetland ecosystems in the Prairie Pothole Region (fig. 1) has been an increase in pond permanence and an overall decrease in salinity (Mushet and others, 2015). However, LaBaugh and others (2016) determined that sustained high water in the region's wetlands can lead to increasing salt loads in some wetland ponds. These shifts in pond permanence and salinity are affecting plant (Winter, 2003), macroinvertebrate (McLean and others, 2016a), and migratory waterfowl communities (Euliss and others, 2004). Transitioning to morepermanently inundated and less-saline wetlands and lakes can increase suitable habitat for fish populations and surface-water connections that facilitate movements and human translocations of fish among habitats (McLean and others, 2016b). Increased fish populations introduce potential forage competition for waterfowl (Cox and others, 1998), and shifts in wetland-plant communities driven by changes in solutes, water levels, or both affect available habitat for reproduction of waterfowl and other wildlife (Steen and others, 2016). Ecosystem changes associated with continued increases in precipitation and temperature have necessitated a rethinking of previously held concepts about wetland functioning (Mushet and others, 2018) and are likely to continue to perpetuate novel biotic interactions (Ballard and others, 2014; Johnson and Poiani, 2016).

Wetlands in the Prairie Pothole Region are imbedded within a matrix of different land uses (Kantrud and others, 1989). Upland land-management practices such as cropping, grazing, and burning can directly affect Prairie Pothole Region wetland water budgets by altering evapotranspiration, infiltration, runoff, and snowmelt dynamics (Renton and others, 2015). Agroecosystems, which are widespread and economically important in the Prairie Pothole Region (Gascoigne and others, 2013), often have surface or subsurface drainage systems designed to move excess water from productive soils (Blann and others, 2009). These drainage systems have effectively removed many wetlands in the Prairie Pothole Region (McCauley and others, 2015). Remaining wetlands often receive drainage water from higher elevation wetlands; thus, wetlands in extensively drained catchments are larger, dry less frequently, and have more surface-water connections to other wetlands than wetlands in undrained landscapes (McCauley and others, 2015). In the United States, the rate of wetland loss because of surface drainage has decreased in recent decades because of the implementation of the "Swampbuster" provisions of the 1985 Food Security Act (Johnston, 2013). However, despite the decrease in surface ditching, the abundance of subsurface tile drains has increased in parts of the Prairie Pothole Region in recent decades (McKenna and others, 2017). Tile-drain installation coincides with a shift towards a wetter climate since 1993 (McKenna and others, 2017) and changing economic conditions that have favored a shift from grasslands and wheat (Triticum aestivum) cropping to corn (Zea mays) and soybean (Glycine max) cropping since 2006 (Wright and Wimberly, 2013). Post van der Burg and others (2016) provided evidence that climate and land-use change in the Prairie Pothole Region are affecting wetland functionality. These changes are large and extensive, and wetland response is highly variable and complex. Understanding and managing wetland and ecosystem responses on a resource-management scale requires sophisticated system modeling tools that do not yet exist.

\section{Wetland Modeling Efforts in the Prairie Pothole Region}

Numerical modeling efforts to develop a mechanistic understanding of the interaction among climate, hydrology, and vegetation dynamics in prairie-pothole wetlands began in the early 1990s (Johnson and Poiani, 2016). The Wetland Simulator (WETSIM) model was the first iteration of this model development (Poiani and Johnson, 1993). WETSIM simulated hydrological and vegetation conditions in one "semipermanent" wetland basin. In WETSIM, the simulated hydrological conditions of the wetland basin interact with a vegetation submodel to simulate changes in the vegetation community. WETSIM has since been modified and expanded into a newer model, WETLANDSCAPE (hereafter "WLS"). The WLS model (Johnson and others, 2010) has increased complexity of the hydrology submodel and, rather than a single wetland, is expanded to simulate 10 wetlands of 3 water-permanence types (temporary $[n=3]$, seasonal $[n=3]$, and semipermanent $[n=4])$ that function together as an interconnected "wetland complex" (Johnson and Poiani, 2016). The WETSIM and WLS models have been used to explore potential future effects of climate change on wetland-pond permanence and vegetation cover (Poiani and others, 1996; Johnson and others, 2016). The overall predictions from WETSIM and WLS are that climate conditions conducive to supporting wetlands with water regimes and vegetation conditions suitable for breeding waterfowl will be limited to the far southeast part of the Prairie Pothole Region by 2100 (Johnson and others, 2005, 2010; Johnson and Poiani, 2016). However, even with 25 years of advances from the WETSIM to the WLS models, this family of models has some fundamental shortcomings.

One of the primary shortcomings of the WETSIM and WLS models is their fixed wetland morphology. The basic morphometry of prairie-pothole wetlands varies among regions within the Prairie Pothole Region (Gleason and Tangen, 2008); for example, wetland pond-volume versus pond-area power functions have very different intercepts and slopes among the physiographic regions of the Prairie Pothole Region (fig. 1). Similarly, Gleason and Tangen (2008) determined that wetland-area versus catchment-area relations also differed greatly among these three physiographic regions. Thus, errors are introduced by using models with static 
wetland morphometries outside of the physiographic region in which their underlying morphometries were developed. Another problem with WETSIM and WLS that brings simulation results into question is their use of static wetland-permanence classes. McKenna and others (2017) and Mushet and others (2018) clearly indicated the need to allow wetlands to shift among permanence classes to capture potential effects of a changing climate. Thus, a priori designation of a wetland as "temporary," "seasonal," or "semipermanent" without allowing shifts among these water-permanence states (McKenna and others, 2017; Mushet and others, 2018) can easily bias multidecadal model runs in which ecohydrological state shifts occur.

Johnson and others (2010) performed WLS runs using climate scenarios in which fluctuations in environmental conditions were spread evenly throughout the year; however, observed changes were not evenly distributed. Temperature increases in the Prairie Pothole Region have been limited primarily to winter months when effects on evapotranspiration are limited. Observed precipitation have increased primarily in spring, when runoff over frozen or saturated soils is enhanced, and in fall, when losses because of evapotranspiration are reduced (McKenna and others, 2017). Additionally, wet conditions during the fall result in increased runoff when snow melts during the ensuing spring. Lastly, the cover-cycle index used by WLS has not been rigorously tested (Renton and others, 2015), yet major regional predictions about waterfowl responses rely on the cover-cycle index (Johnson and Poiani, 2016). There is still a need to develop a better mechanistic understanding of how climate, hydrology, chemistry, and time affect vegetation communities and ultimately other biota, including waterfowl, of prairie-pothole wetlands.

As part of the U.S. Department of Agriculture Conservation Effects and Assessment Project (Wetlands), we began developing an open-source system model that better encapsulated the heterogeneity of prairie-pothole wetland ecosystems and incorporated wetland responses to different climate states (Mushet and Scherff, 2016). Under the U.S. Geological Survey Climate Research and Development Program, we refined and expanded the basic hydrology model and included salinity dynamics of prairie-pothole wetlands (fig. 2). Our goal was to provide an open-source numerical model that accurately simulates the hydrological, geochemical, and biological dynamics of prairie-pothole wetland ecosystems. The PHyLiSS model is the result of our efforts and the first iteration of a coupled hydrologic-hydrogeochemical and biological simulation model for prairie-pothole wetlands (fig. 3).

\section{Pothole Hydrology-Linked Systems Simulator (PHyLiSS) Model Documentation}

PHyLiSS is a systems model for exploring the effects of climate and land-use change on prairie-pothole wetland ecosystems. PHyLiSS was developed using Stella Professional (ver. 1.4) software. Stella provides a graphical user interface for developing models using stocks and flow diagrams (fig. 3). Mathematically, the system that is created in Stella numerically solves an interconnected set of differential equations (Costanza and Voinov, 2001). Currently, the model simulates water-surface elevation dynamics in prairie-pothole wetlands and quantifies changes in salinity on a daily time step. Surface-water inputs in the model include precipitation, runoff from upland areas of the wetland catchment, and snowmelt. Outputs from the wetland include evaporation, transpiration, and spill to and from other wetlands. Groundwater inputs and outputs are modeled indirectly relative to the target wetland's position along a recharge-to-discharge landscape gradient. Geochemical composition of wetland water is driven by hydrologic, meteorological, and topographic variables. We plan to incorporate the effects of these hydrological and geochemical drivers on the plant and other biotic communities of prairie wetlands into future versions of PHyLiSS.

\section{Hydrology Submodel}

The hydrological component of PHyLiSS is based on the following water-balance equation:

$$
W=P+Q-E-T+S_{i}-S_{o}+G_{i}-G_{o}
$$

where
$W \quad$ is wetland volume, in cubic meters;
$P \quad$ is precipitation, in cubic meters;
$Q \quad$ is runoff generated, in cubic meters;
$E$ is evaporation, in cubic meters;
$T$ is transpiration, in cubic meters;
$S_{i} \quad$ is spill inflow, in cubic meters;
$S_{o} \quad$ is spill outflow, in cubic meters;
$G_{i} \quad$ is groundwater inflow, in cubic meters; and
$G_{o} \quad$ is groundwater outflow, in cubic meters.

Wetland volume $(W)$ is the volume of ponded water in the wetland pool. Water can be added to a wetland pond by precipitation $(P)$ on the ponded-water surface, $\operatorname{runoff}(Q)$ from its local catchment, spill inflow $\left(S_{i}\right)$ from adjacent wetland basins, and groundwater inflow $\left(G_{i}\right)$. Runoff can be from rainfall or snowmelt. Water can be lost through evaporation $(E)$, transpiration $(T)$, spill outflow $\left(S_{o}\right)$ into an adjacent wetland basin, and groundwater outflow $\left(G_{o}\right)$. Groundwater and surface-spill 


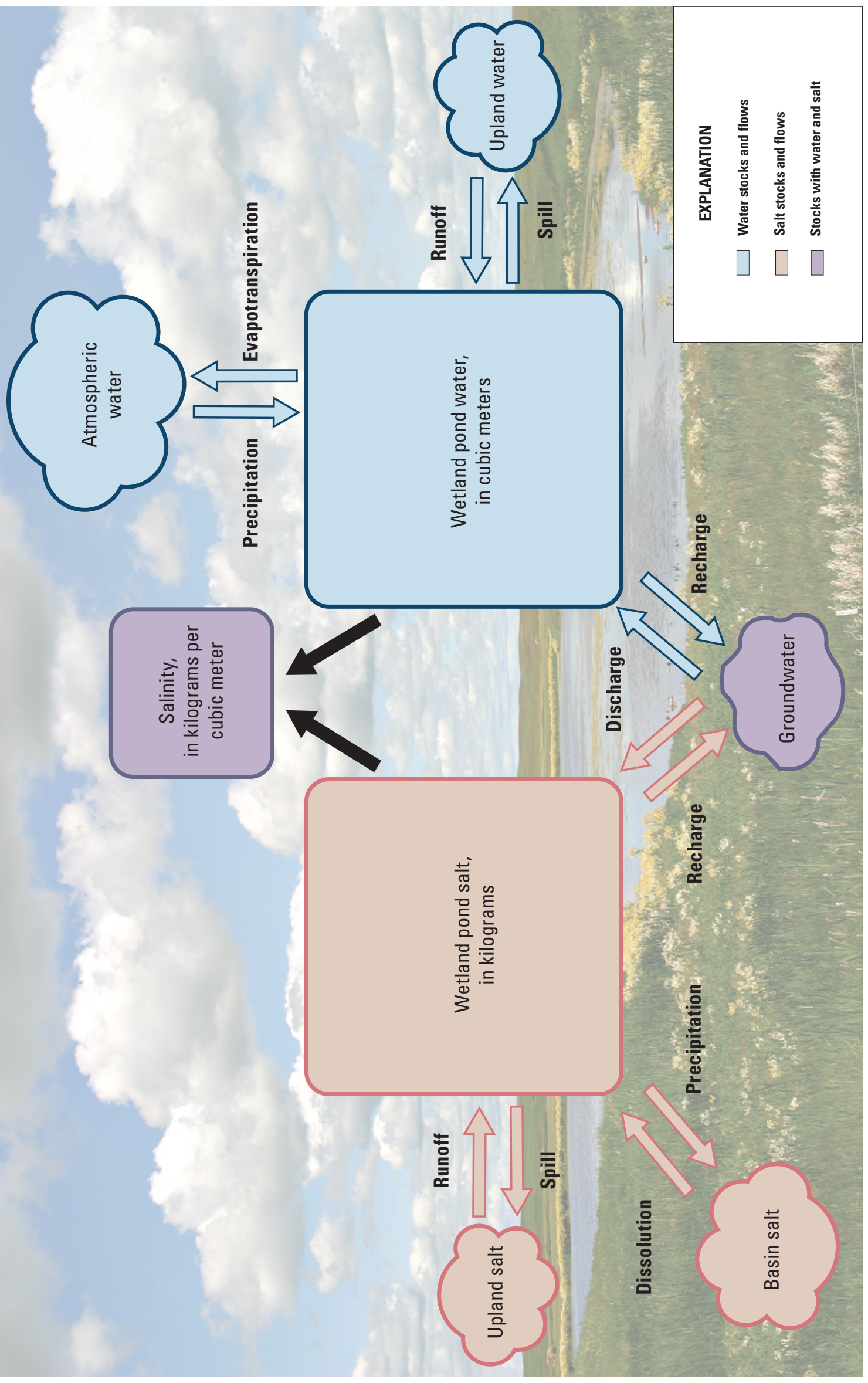

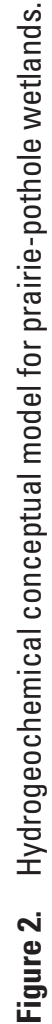




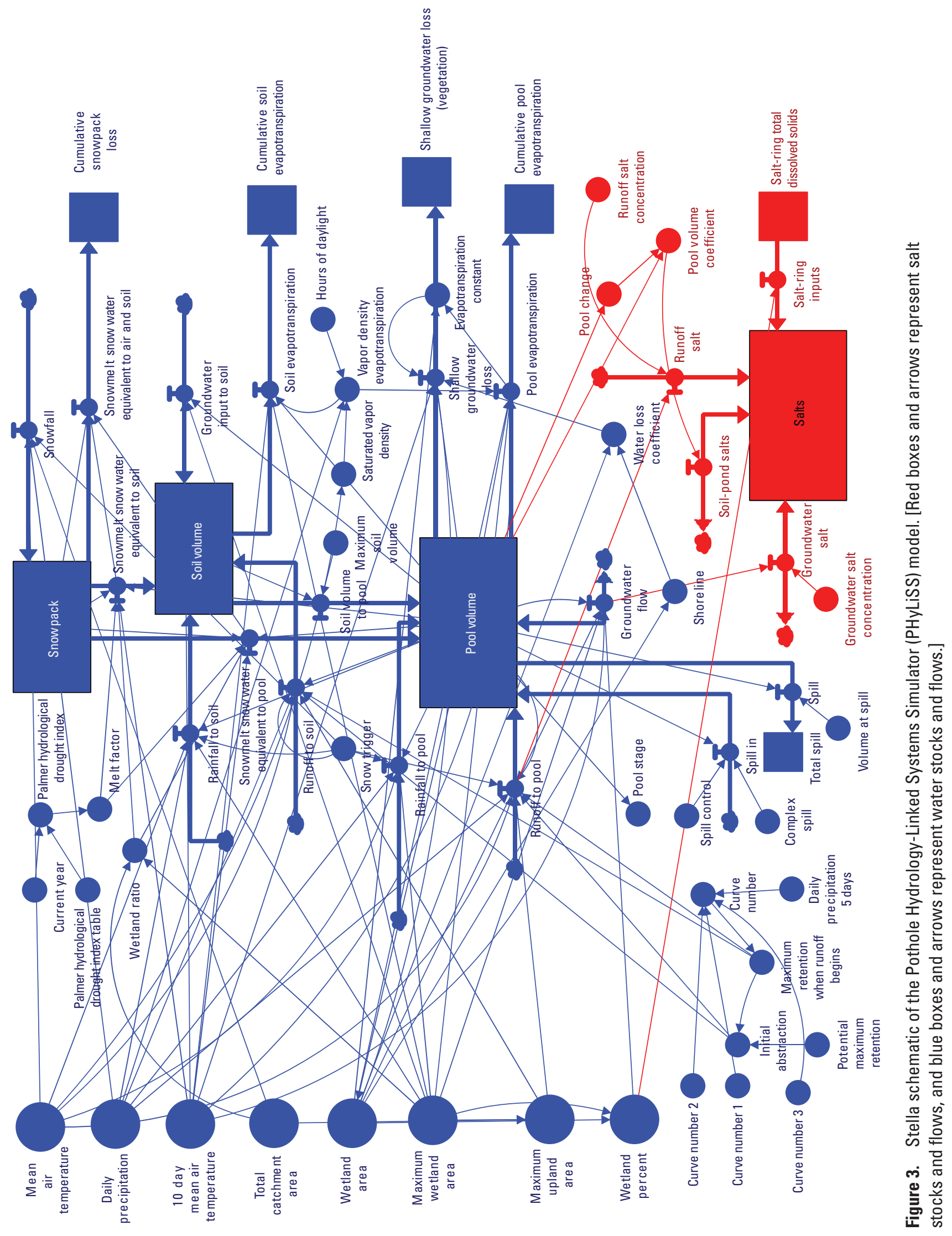


processes depend on the relative position of a wetland on a groundwater recharge-to-discharge gradient and its elevation relative to that of the adjacent water table. Groundwater flows are bidirectional in PHyLiSS. This functionality allows for the model to simulate extreme drought periods when discharge wetlands change to function similar to recharge wetlands (Levy and others, 2018b).

\section{Precipitation, Runoff, and Snowmelt}

In PHyLiSS simulations, precipitation adds to the wetland water volume directly when air temperature is above 0 degree Celsius $\left({ }^{\circ} \mathrm{C}\right)$. Runoff from the upland component of the wetland catchment also can be generated when air temperature is above $0{ }^{\circ} \mathrm{C}$. Runoff from the catchment is derived using the Soil Conservation Service Runoff Curve Number method (Cronshey and others, 1986). Table 1 gives examples of runoff curve numbers for different land covers and degrees of wetness. The following equations (converted from U.S. customary units [inches] to the System of International Units [meters]) describe the Runoff Curve Number method (Cronshey and others, 1986):

$$
\begin{gathered}
Q=\frac{\left(P-I_{a}\right)^{2}}{\left(\left(P-I_{a}\right)+S\right)^{* A}} \\
I_{a}=0.2 \times S \\
S=\frac{1,000}{C N}-10
\end{gathered}
$$

where

$$
\begin{array}{cl}
Q & \text { is runoff generated, in cubic meters; } \\
P & \text { is daily precipitation, in meters; } \\
I_{a} & \text { is initial abstraction, in meters; } \\
S & \text { is potential maximum retention after runoff } \\
& \text { begins, in meters; } \\
C N & \text { is the Soil Conservation Service runoff curve } \\
& \text { number; and } \\
A & \text { is wetland area, in square meters. }
\end{array}
$$

Runoff curve numbers used in our model validation are provided in table 1 .

Table 1. Soil Conservation Service Runoff Curve Numbers by land cover (Cronshey and others, 1986).

$[\mathrm{CN}$, curve number]

\begin{tabular}{lccc}
\hline \multicolumn{1}{c}{ CN } & Meadow & Grazed pasture & Row crops \\
\hline CN I (dry) & 36.7 & 48.3 & 59.8 \\
CN II (average) & 58.0 & 69.0 & 78.0 \\
CN III (wet) & 76.0 & 83.7 & 89.1 \\
\hline
\end{tabular}

When air temperature is $0{ }^{\circ} \mathrm{C}$ or below, precipitation for the wetland catchment accumulates in a snowpack reservoir. Water from the snowpack reservoir can only add to the wetland water volume during simulated snowmelt that occurs when the 10-day mean air temperature exceeds $3{ }^{\circ} \mathrm{C}$ (Johnson and others, 2010). When this 10-day mean temperature threshold is reached, snowmelt is divided between two pathways, runoff and infiltration. The proportion of water stored in the snowpack that is transferred to the wetland basin during snowmelt is affected by the antecedent soil-moisture condition of the catchment (Winter and Rosenberry, 1995). When soils are dry, a larger fraction of melt water becomes infiltration that recharges upland soils. When soils are wetter, less melt water infiltrates the soil and a larger fraction becomes runoff that moves into the wetland (Fang and Pomeroy, 2007). To account for this relation, we developed a melt factor that ranges from 0 to 1 and controls the fraction of snowpack that becomes runoff into the wetland. To determine the melt factor for a given year, we first approximated the amount of water received annually by spring snowmelt. We used long-term (1982-2015) waterlevel data from five prairie-pothole wetlands to approximate the amount of water that each wetland received. We used the technique developed by LaBaugh and others (2018) to approximate snowmelt inputs. This technique uses the last pond volume in fall and the first pond volume in the following spring to quantify snowmelt inputs. We then estimated the snowpack volume based on the sum of precipitation, from weather station data, during the winter when air temperature was below $0{ }^{\circ} \mathrm{C}$ and before snowmelt began. We then evaluated relations between the proportion of snowpack needed to fill the wetlands and monthly Palmer Drought Severity Index and Palmer Hydrological Drought Index (PHDI) values for different fall months preceding the spring snowmelt. We found a strong linear relation (coefficient of determination $=0.53$; $p$-value $=0.01$ ) between the monthly PHDI from the preceding October and the value of the melt factor for the current year. We then incorporated melt factors into PHyLiSS that range from 0 to 1 and decrease logistically over a range of October PHDI values from 7.84 to -6.17 . In addition to the upland snowmelt runoff, all the snowpack within the wetland is directly added to the wetland water volume during snowmelt.

\section{Fill-and-Spill}

Spill occurs when a wetland fills beyond the maximum elevation of its basin and water flows overland out of the basin, potentially to an adjacent wetland basin. This phenomenon is known as fill-and-spill (Leibowitz and others, 2016). Fill-and-spill may not be frequent but can be important for the transfer of salts and aquatic biota among wetland basins (Hayashi and others, 2016). PHyLiSS can capture spill into and out of a wetland. To incorporate fill-and-spill dynamics for a given wetland basin, a spill-point elevation is set and used to calculate the maximum volume of water the basin can hold before spilling. When the calculated pool volume is greater than maximum volume of the wetland basin, excess water 
is removed in the next time step. If a downgradient wetland is subsequently modeled, this removed excess water forms an input to that wetland. This process is expanded as needed based on the modeled domain to model multiple wetlands at differing topographic positions in a prairie-pothole landscape. Through this iterative process, any number of wetlands functioning as an interacting wetland complex (Johnson and others, 2010) can be modeled with PHyLiSS.

\section{Evaporation and Transpiration Losses}

In the PHyLiSS model, water can move from the wetland to the atmosphere through two pathways that represent abiotic and biotic processes. The Hamon equation was an appropriate method for determining evapotranspiration in the Prairie Pothole Region (Rosenberry and others, 2004). The Hamon equation (Hamon, 1961) for estimating evaporation is

$$
E=\frac{\left(.55 \times\left(\frac{D}{12}\right)^{2} \times\left(\frac{S V D}{100}\right) \times 25.4\right.}{1,000} \times A
$$

where

$$
\begin{aligned}
E & \text { is evaporation, in cubic meters; } \\
D & \text { is daylight, in hours; } \\
S V D & \text { is saturated vapor density, in grams per cubic } \\
& \text { meters; and } \\
A & \text { is wetland area, in square meters. }
\end{aligned}
$$

Saturated vapor density (in grams per cubic meter) is be estimated by using the polynomial relation with mean daily air temperature (in degrees Celsius) from LaBaugh and others (2018):

$$
\begin{aligned}
S V D= & 5.018+0.32321 \times T a+0.0081847 \\
& \times T a^{2}+0.00031243 \times T a^{3}
\end{aligned}
$$

where

$$
\begin{gathered}
\text { SVD saturated vapor density, in grams per cubic } \\
\text { meter; and } \\
T a \quad \text { is mean daily air temperature, in degrees } \\
\text { Celsius. }
\end{gathered}
$$

When there is no ponded water, evaporation is reduced by 25 percent of the evaporation estimated by the Hamon equation. In addition to physical open-water/soil evaporation, PHyLiSS also includes an estimate of water losses via transpiration from vegetation along the edge of the wetland. This phenomenon is an important component in the water budgets of prairie-pothole wetlands (Hayashi and others, 1998; van der Kamp and Hayashi, 2009). A strong linear correlation exists between the rate of water-level recession caused by transpiration, which we refer to as shallow groundwater loss, and the ratio of the pond shoreline length (in meters) to the pond area (in square meters; van der Kamp and Hayashi, 2009). As a wetland reduces in size, PHyLiSS uses a parameterization from Huang and others (2013) to estimate these shallow groundwater losses:

$$
S G W_{t}=R S_{\text {ref }} \times\left(E \div E_{\text {ref }}\right) \times \text { Ratio } \times A
$$

where

$$
\begin{aligned}
& S G W_{t} \quad \text { is shallow groundwater loss, in cubic meters; } \\
& R S_{r e f} \quad \text { is the reference recession slope, in square } \\
& \text { meters per day; } \\
& E \quad \text { is evaporation from equation } 4 \text {, in meters per } \\
& \text { day; } \\
& E_{r e f} \text { is max open-water evaporation, in meters per } \\
& \text { day; } \\
& \text { Ratio is the ratio of shoreline length, in meters, to } \\
& \text { wetland area, in square meters; and } \\
& A \text { is wetland area, in square meters. }
\end{aligned}
$$

We used $R S_{\text {ref }}=0.04$ square meter per day and $E_{\text {ref }}=0.0035$ meter per day from Huang and others (2013) to parameterize PHyLiSS.

\section{Subsurface Water Dynamics}

The subsurface water dynamics of prairie-pothole wetlands are simulated in PHyLiSS using a soil-water reservoir that accounts for below-ground water stores in the modeled wetland basin. The soil-water reservoir in PHyLiSS is a simplification of complex groundwater dynamics that allows a wetland to continue drying even after the surface pool volume has been completely depleted. The use of a "double-bucket" approach has been used in other pothole modeling efforts to better simulate prairie-pothole wetland hydrology (Johnson and Poiani, 2016). In PHyLiSS, this soil-water reservoir needs to be recharged completely before water inputs add to the surface-water pond. Likewise, when the surface-water pond empties, any additional water losses are subtracted from the underlying soil-water reservoir. Groundwater can enter or exit the wetland depending on the local groundwater table elevation relative to the bottom elevation of the wetland basin. When calibrating PHyLiSS, we estimated groundwater inputs and outflows for a wetland based on local water-table data and the remaining difference in the water-balance equation that the other components of the model could not account for. Groundwater inflows for Cottonwood Lake study area discharge wetlands were in the range of literature value estimates from the region (table 2). Groundwater inflow reverses to outflow in discharge wetlands whenever the pool volume is less than 20 percent of the wetland basin. This threshold was set to match known discharge-to-recharge shifts that occurred during drought periods in a set of study wetlands in North Dakota (Levy and others, 2018b). Groundwater outflow rates for recharge wetlands also were estimated within the range of literature values from the region (table 2).

\section{Geochemistry Submodel}

PHyLiSS directly simulates salts as the mass, in kilograms, of total dissolved solids (TDS) in a wetland, through a mass balance approach. The geochemical component of 
Table 2. Annual groundwater recharge and discharge estimates.

[--, no data; W., west; St., saint]

\begin{tabular}{llcc}
\hline \multicolumn{1}{c}{ Source } & \multicolumn{1}{c}{ Wetland } & $\begin{array}{c}\text { Recharge, } \\
\text { in millimeters per year }\end{array}$ & $\begin{array}{c}\text { Discharge, } \\
\text { in millimeters per year }\end{array}$ \\
\hline LaBaugh and others (2018) & P1 at Cottonwood Lake study area (1979-1987) & -- & $10-100$ \\
LaBaugh and others (2018) & P1 at Cottonwood Lake study area (1988-1992) & $10-100$ & -- \\
LaBaugh and others (2018) & P1 at Cottonwood Lake study area (1993-1998) & -- & $100-200$ \\
Rehm and others (1982) & W. North Dakota, United States & $10-40$ & -- \\
Hayashi and others (1998) & St. Denis, Canada & $1-3$ & -- \\
\hline
\end{tabular}

PHyLiSS is based on a simplified conceptual model (fig. 2) in which solutes can enter a wetland through discharge from groundwater dissolution of local basin salts, and upland water. In the model, it is assumed that dissolved ions in precipitation inputs are a negligible component of the solute inputs. LaBaugh and others (2018) determined that, over a 20-year period, greater than 90 percent of dissolved ions entered their study from sources other than precipitation inputs. PHyLiSS also considers solute losses from wetlands via precipitationmediated movement through dry sediment cracks (Levy and others, 2018b) and movement into adjacent soils through evapotranspiration (Winter and Rosenberry, 1995). PHyLiSS does not directly include wind-driven losses of salts, although in rare cases this phenomenon has been documented to occur under conditions of severe drought (LaBaugh and others, 1996).

\section{Subsurface Water-Salt Dynamics}

Precipitation and evapotranspiration are the main drivers of prairie-pothole wetland hydrology (Hayashi and others, 2016). However, these wetlands also can receive inputs from, or exports to, local groundwater reservoirs depending on the hydrogeological setting. The direction of groundwater movement can vary temporally in response to climate effects on water volumes. Groundwater is the smallest component of prairie-pothole wetland water budgets (LaBaugh and others, 2018), and the groundwater inputs and losses mainly affect the wetland-chemistry dynamics. Wetlands only recharge surface water to groundwater when situated above the local water table. Ponded water in these wetlands can infiltrate into groundwater reservoirs. Wetlands also can be areas of groundwater discharge when they are at the lowest elevations in a local flow domain. Groundwater also can simultaneously enter and leave a wetland that is on the midslope of a prairie-pothole wetland landscape.

Localized groundwater in the Prairie Pothole Region contains high levels of salts from oxidized glacial till (Goldhaber and others, 2011). Groundwater inputs to discharge wetlands can have especially high concentrations of salts (Levy and others, 2018a). Groundwater can enter prairie-potholewetland ponds if the water table is higher than the elevation of the wetland basin. In PHyLiSS, a wetland can gain or lose water from or to groundwater. We use fluctuations between groundwater recharge and discharge functions to estimate groundwater-salt dynamics. Wetlands at the recharge end of the gradient do not have groundwater inputs; the salt dynamics in the pond are driven solely by atmospheric water dissolution and concentration of salts due to evaporation of water (Nachshon and others, 2013). At the other extreme, discharge wetlands only receive inputs from groundwater. PHyLiSS uses a constant to estimate groundwater-salt inputs and outflows to and from wetlands based on solute concentrations in neighboring groundwater wells. The TDS concentration values for each wetland were estimated from local groundwater well data (Mushet and others, 2017). This relation is bidirectional so that wetlands can perform either recharge or discharge functions as affected by water levels and climatic conditions (Levy and others, 2018a).

\section{Soil-Salt Dynamics}

PHyLiSS allows pond water to interact with soil solutes by two different mechanisms. Support for these mechanisms comes from empirical geoelectrical surveys (Levy and others, 2018a) and hydrochemical studies (Winter and Rosenberry, 1995; Levy and others, 2018b) of a prairie-pothole wetland in Stutsman County, North Dakota (fig. 4). The first mechanism of solute transfer is dependent on the volume of the pool as a proxy for ponded surface area interacting with salt and saline pore fluid in soils. This mechanism of soil-to-pond salt transfer is bidirectional. If the wetland-pond volume is increasing, then the salt input is positive; if the wetland-pond volume is decreasing, then the salt input is negative. The loss of salts with decreasing pond volume is supported by the loss of pond water including its dissolved solids to a groundwater trough that can form because of high rates of transpiration at the wetland edge (Rosenberry and Winter, 1997). This mechanism likely transfers solutes to and from the pond water at a slower rate than that of the near-surface transfer of solutes via salt ring dissolution (that is, the second mechanism of solute transfer).

When the pond inundates a well-established salt ring during a high-water event, solute transfers occur. We assume 


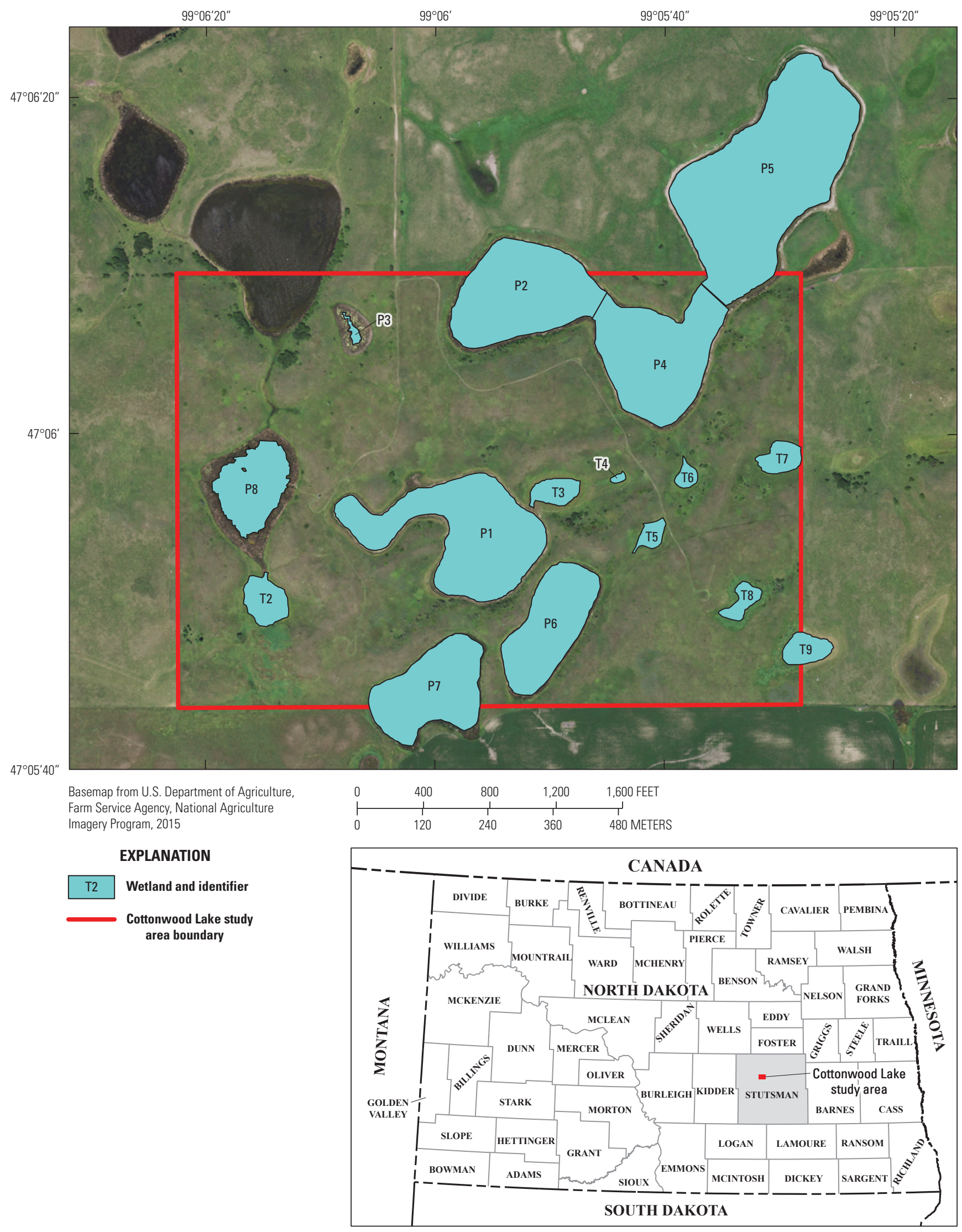

Figure 4. Prairie-pothole wetlands in the Cottonwood Lake study area, Stutsman County, North Dakota. 
a finite amount of precipitated salts and high-saline pore water in salt rings that had been established before the high-water event is readily transferred to the pond water. The transfer rate is much quicker than the first mechanism. This is supported by the presence of relatively shallow, saline pore water that transfers quickly to pond water. The location of the salt ring for each pond was determined by long-term aerial photography analysis. We identified the period between 1993 and 2000 as one where the existing salt ring became inundated as wetland area increased. The relation between pond solute mass and magnitude of the readily available salt stock was estimated by the amount of salts unexplained by the first mechanism during the state-change period (1993-2000). When the salt ring is inundated, then the salt-ring stock begins to transfer to the wetland pond.

\section{Biotic Submodels}

We plan to release future versions of PHyLiSS that should include additional submodels. These proposed submodels would simulate the effects of hydrological and geochemical drivers on the biotic communities of prairie wetlands. Plant and aquatic-macroinvertebrate communities will be the focus of the next submodels developed, and the submodels will use abiotic and biotic relations identified using structural equation modeling and other techniques. Simulating responses to plant and aquatic macroinvertebrate communities will allow us to better predict the future suitability of prairie-pothole wetlands as habitat for waterfowl, shorebirds, and other wetland dependent bird species.

\section{Model Validation}

We parameterized and validated PHyLiSS using a 30 -year hydrology dataset and a 20 -year water-chemistry dataset from six prairie-pothole wetlands ( $\mathrm{P} 1, \mathrm{P} 6, \mathrm{P} 7, \mathrm{~T} 5, \mathrm{~T} 8$, and T9) in the Cottonwood Lake study area (table 3; fig. 4). The Cottonwood Lake study area is a 92-hectare prairiepothole wetland complex in Stutsman County, North Dakota, that has been the subject of long-term ecological and hydrological study by the U.S. Geological Survey since the 1960s (Winter, 2003). The Cottonwood Lake study area contains 17 prairie-pothole wetlands situated across an elevational gradient of about $33 \mathrm{~m}$. We used the long-term data assets for six wetlands in the Cottonwood Lake study area complex in our model validations (table 3). All hydrology, chemistry, and biology datasets in addition to high-resolution landsurface elevation data for the Cottonwood Lake study area are publicly available from the Missouri Coteau Wetland Ecosystem Observatory at https://www.sciencebase.gov/catalog/ item/52f0ffd9e4b0f941aa181fc6. We conducted simple linear regression analysis on modeled versus observed wetland-water volume and TDS to check model fit. PHyLiSS accurately predicted the initial water volume (observed stage) in the spring of each year and the seasonal water dynamics during the summer months for a variety of wetlands (fig. 5). PHyLiSS also successfully tracked a period of drought (mid-1980s to early 1990s), during which most of the ponded water in wetlands completely dried, and a period of deluge (early 1990s to early 2000s), during which historically high-water levels were observed at the site.

\section{Hydrology Submodel Validation}

The model was calibrated to simulate hydrology of any given prairie-pothole wetland, regardless of size or location on the landscape (table 4). We validated the model against observed data (1982-2015) from six Cottonwood Lake study area wetlands that varied in size and relative topographic position (table 3; fig. 5). Because PHyLiSS is dynamic and generalizable, there are some wetlands for which PHyLiSS modeled hydrology better than others (table 4; fig. 5). The smaller wetlands are much more variable and their small pool volumes and short hydroperiods are difficult to re-create accurately; thus, modeled wetland stage for the smallest wetlands have the weakest fit. However, figure 4 shows that PHyLiSS can reliably simulate conditions for years when these smallest wetlands (T5, T8, and T9) were dry and years when their water levels were high. From a waterfowl-use perspective,

Table 3. Cottonwood Lake study area validation wetland characteristics.

\begin{tabular}{|c|c|c|c|c|c|}
\hline Wetland name & $\begin{array}{c}\text { Maximum } \\
\text { wetland area, } \\
\text { in hectares } \\
(1982-2015)\end{array}$ & $\begin{array}{c}\text { Wetland elevation, } \\
\text { in meters above } \\
\text { sea level }\end{array}$ & $\begin{array}{c}\text { Catchment area, } \\
\text { in hectares }\end{array}$ & $\begin{array}{l}\text { Maximum pond depth, } \\
\text { in meters } \\
(1982-2015)\end{array}$ & $\begin{array}{c}\text { Average conductance, } \\
\text { in microsiemens per } \\
\text { centimenter at } 25 \text { degrees } \\
\text { Celsius } \\
(1994-2015)\end{array}$ \\
\hline $\mathrm{P} 1$ & 66.5 & 558.0 & 97.9 & 2.82 & 2,604 \\
\hline P6 & 29.5 & 560.3 & 94.1 & 3.04 & 1,303 \\
\hline $\mathrm{T} 5$ & 0.2 & 569.6 & 20.8 & 1.56 & 170 \\
\hline $\mathrm{T} 8$ & 0.9 & 577.1 & 25.5 & 1.42 & 201 \\
\hline T9 & 1.6 & 576.2 & 36.2 & 1.54 & 306 \\
\hline
\end{tabular}



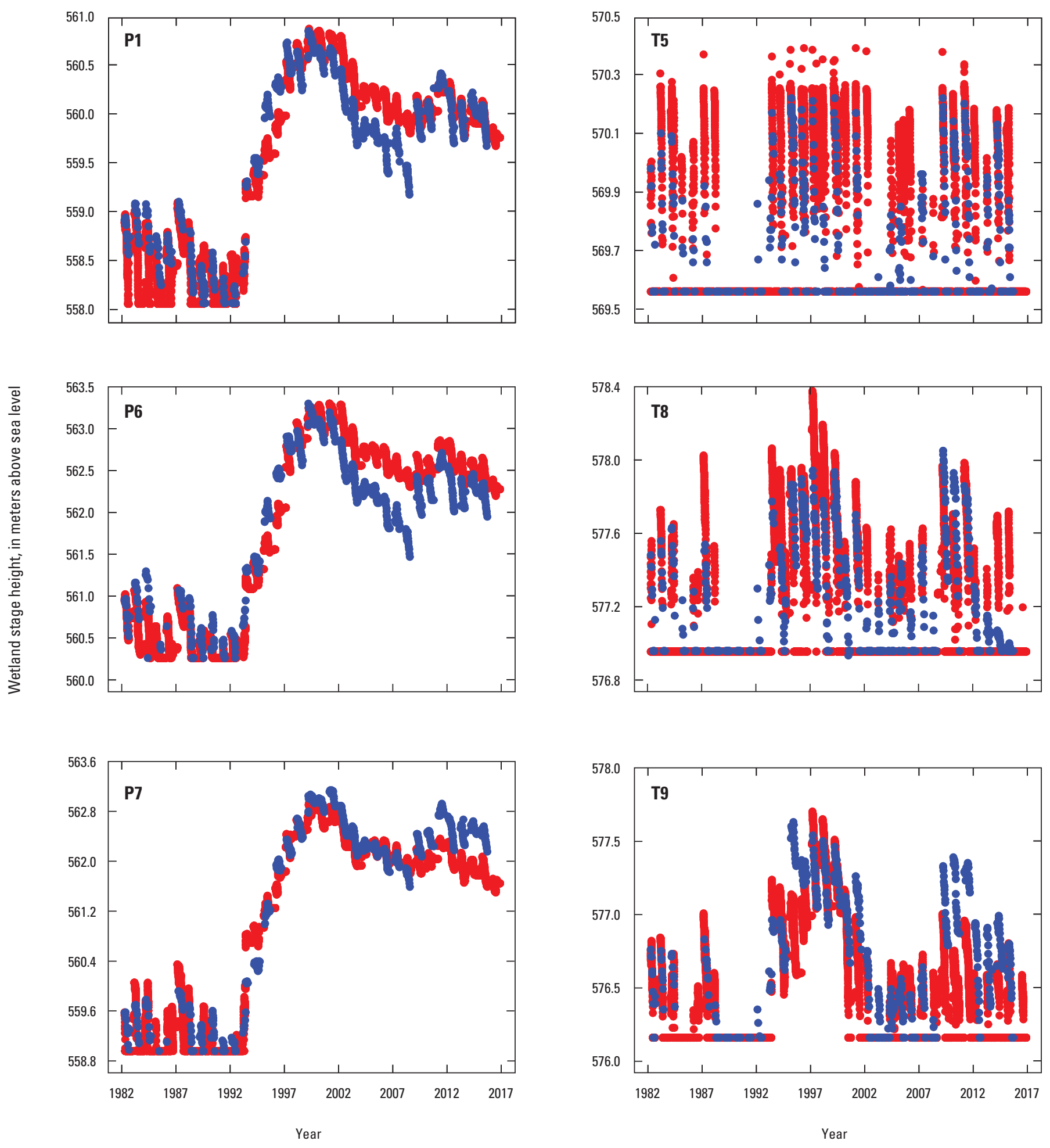

EXPLANATION

- Modeled

- Observed

Figure 5. Observed versus modeled water levels for six wetlands in the Cottonwood Lake study area, Stutsman County, North Dakota. 
Table 4. Regression analysis for modeled versus observed wetland stage validation.

\begin{tabular}{llll}
\hline \multicolumn{1}{c}{ Wetland } & Fit & Slope & $\boldsymbol{p}$-value \\
\hline P1 & 0.90 & 1.07 & $<0.001$ \\
P6 & 0.90 & 1.12 & $<0.001$ \\
P7 & 0.95 & 0.94 & $<0.001$ \\
T5 & 0.31 & 0.61 & $<0.001$ \\
T8 & 0.56 & 0.89 & $<0.001$ \\
T9 & 0.63 & 0.75 & $<0.001$ \\
\hline
\end{tabular}

being able to predict when wetlands are completely dry can be more important than modeling the actual amount of water in the wetland at a given time. PHyLiSS also was able to reliably track large changes in wetland surface-water stage during dry periods and through a recent climate shift in which the hydrological function of many wetlands changed to that of a lake state (McKenna and others, 2017). We also used local estimates of groundwater recharge and discharge to check the validity of the estimates made by PHyLiSS (table 2).

\section{Salinity Submodel Validation}

PHyLiSS also reliably simulated TDS in three semipermanently inundated prairie-pothole wetlands (P1, P6, and P7; table 5; fig. 6). The major difference between the TDS stock of each semipermanently inundated wetland was development of the salt ring. Wetland P1 is the lowest elevation of the three wetlands modeled (table 3 ), receives the greatest groundwater inputs, and has a well-established salt ring. Wetlands P6 and P7 do not receive as much groundwater, and with less sulfate input there is less salt-ring development. Salt-ring dynamics are very important when a wetland becomes consistently inundated and the new shoreline moves beyond previous levels (LaBaugh and others, 2018). For model calibration, empirical data were used to manipulate salt-ring stock size for each wetland relative to the wetland size and groundwater inputs. The recharge-discharge dynamics also were important to consider in the case of larger wetlands because when they dry, solutes are lost from precipitation flushing into deep wetland sediments (Levy and others, 2018b).

Table 5. Regression analysis for modeled versus observed wetland total dissolved solids validation.

\begin{tabular}{lccc}
\hline \multicolumn{1}{c}{ Wetland } & Fit & Slope & p-value \\
\hline P1 & 0.92 & 0.91 & $<0.001$ \\
P6 & 0.83 & 0.86 & $<0.001$ \\
P7 & 0.75 & 0.49 & $<0.001$ \\
\hline
\end{tabular}

\section{Using the Pothole Hydrology-Linked Systems Simulator (PHyLiSS) Model}

PHyLiSS was developed using Stella Professional (ver. 1.4), which runs Stella (ver. 10.1.2). The model can be obtained through the USGS ScienceBase Catalog at https://www.sciencebase.gov/catalog/ item/5b840f3ee4b05f6e 321b4f04. Files are stored with the .STMX extension. STMX files can be accessed in any isee systems program using Stella version 10.0 or above. Stella is compatible with Windows and macOS. Users will need a copy of Stella to access the full version of PHyLiSS. Software documentation and tutorials for Stella are available through isee systems, inc., at https://www.iseesystems.com/resources/ help/v1-4/default.htm. Users can use the Stella model window to configure the stock and flow relations of the model (fig. 3) and edit the corresponding computational equations. Stella supports tables, graphs, and numeric displays as output objects built into the model and has additional tools for viewing and analyzing model behavior. Additionally, a limited version of PHyLiSS can be accessed at no cost through the interface described in the "Stella Architect Interface" section.

\section{User Inputs}

PHyLiSS input data can be customized to match the climate, morphology, land-use, and antecedent hydrology and salt conditions of a given wetland basin. Specific user input variables needed to run PHyLiSS are provided in table 6. Once all user inputs are complete, then the start time, stop time, and time units can be configured to match the duration of the user's specific model run. The table and graph features in Stella can be used to visualize and export output data of any stock, flow, or variable from PHyLiSS to a .csv files.

\section{Linking Wetlands into a Complex}

A wetland can receive surface water from adjacent and higher-elevation wetlands during spill-and-fill. To incorporate the water volumes that enter a wetland via "spill in," the user must run the simulation of the wetland at the highest elevation that contributes to the spill water volume. Then, each subsequent wetland must be modeled to add in the total spill water volume to the lowest elevation wetland. The total spill water volume is input as the "complex spill" variable. A value for spill is needed for each time step that the model runs.

\section{Stella Architect Interface}

We developed a Stella Architect user interface as an easy and free way to access a limited version of the PHyLiSS model (fig. 7). However, this version has limited capabilities 

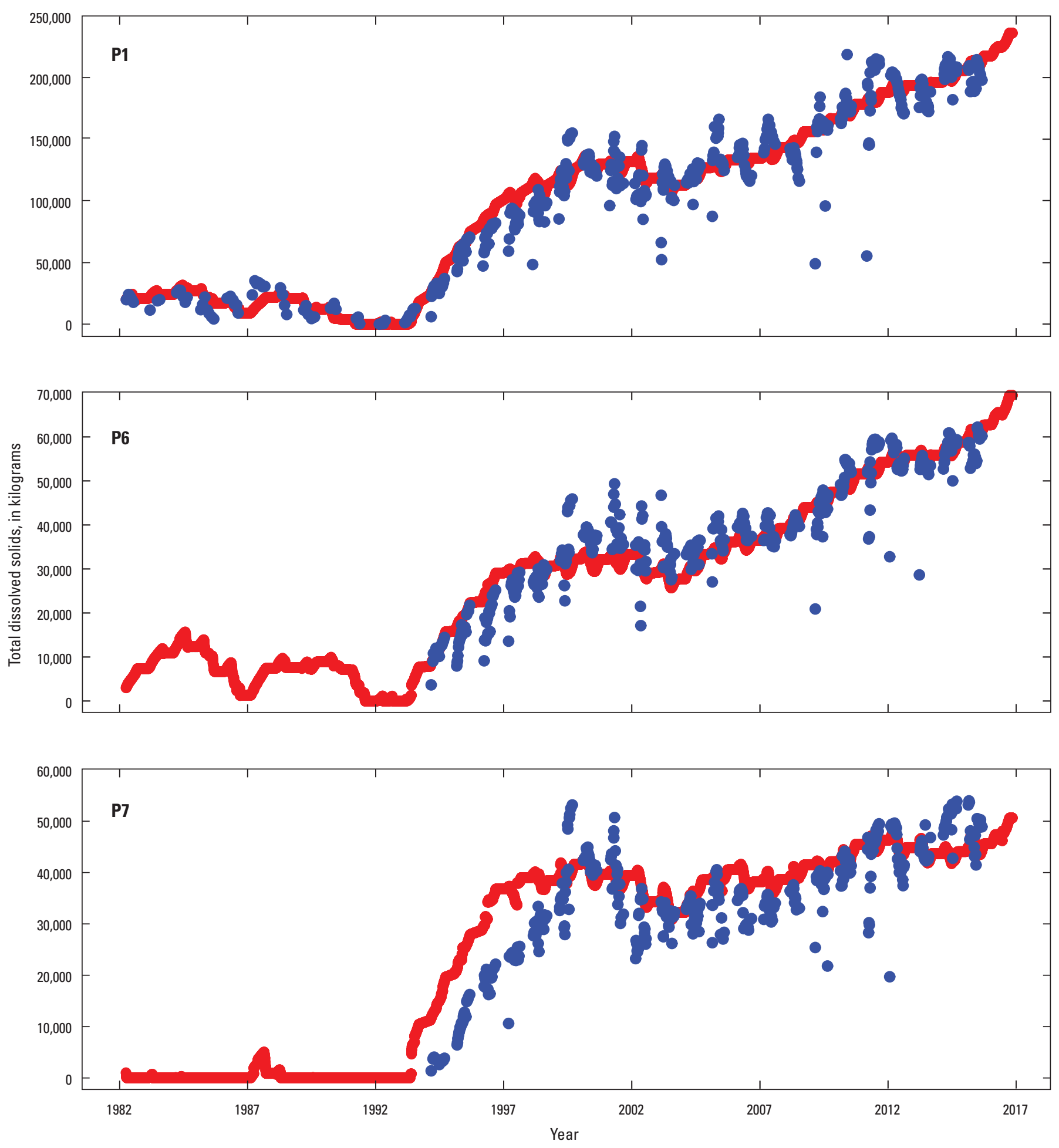

EXPLANATION

- Modeled

Observed

Figure 6. Observed versus modeled total dissolved solids in wetlands P1, P6, and P7 in the Cottonwood Lake study area, Stutsman County, North Dakota. 
Table 6. User inputs needed to run the Pothole Hydrology-Linked Systems Simulator (PHyLiSS) model for a given prairie-pothole wetland.

$\left[{ }^{\circ} \mathrm{C}\right.$, degree Celsius; --, none; in., inch; ET, evapotranspiration; PHDI, Palmer Hydrological Drought Index; $\mathrm{m}^{2}$, square meter; $\mathrm{m}^{3}$, cubic meter; masl, meter above sea level; N/A, not applicable; TDS, total dissolved solids; $\mathrm{kg}$, kilogram; $\mathrm{kg} / \mathrm{m}^{3}$, kilogram per cubic meter]

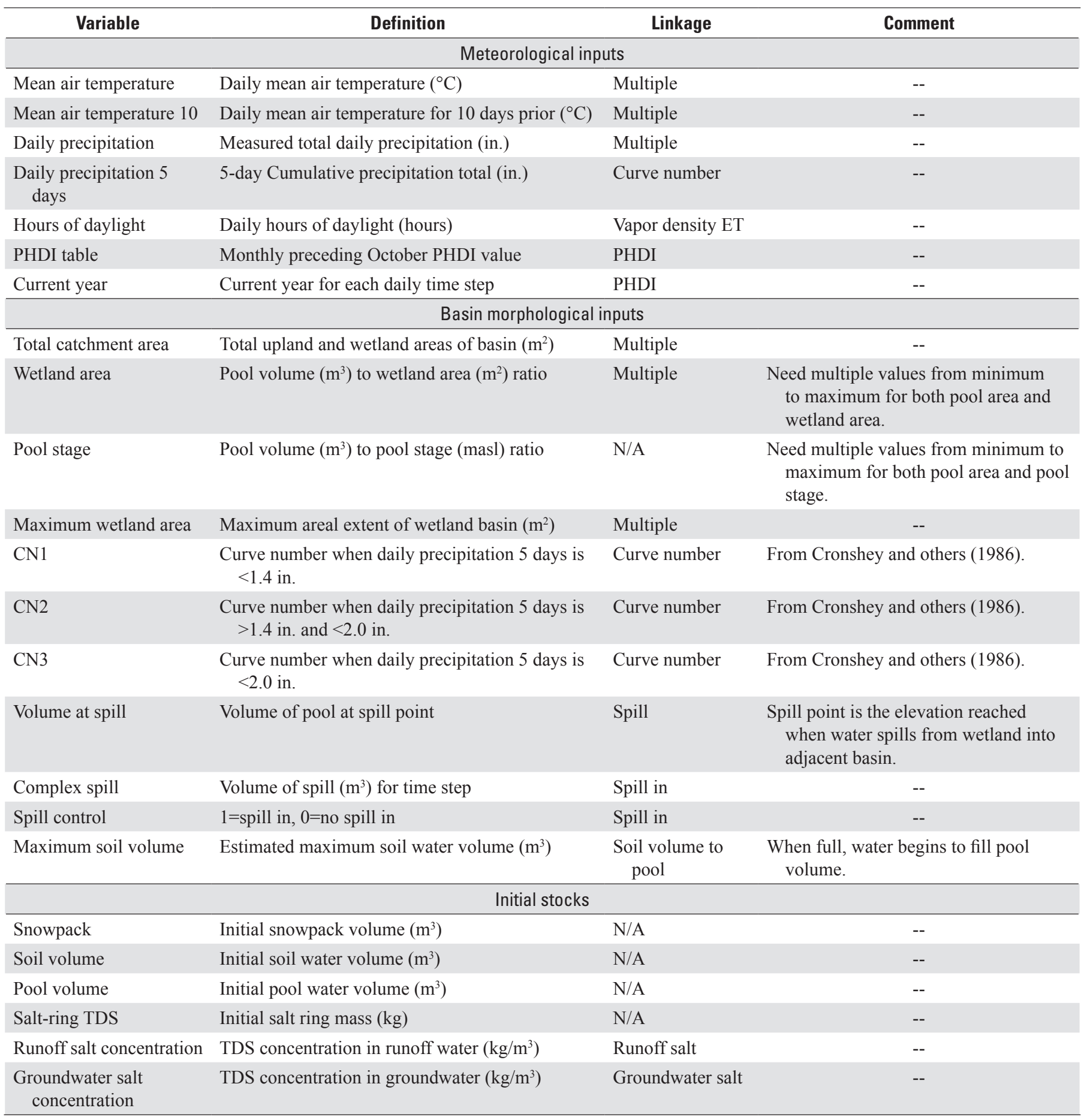




\section{₹USGS Pothole Hydrology Linked Systems Simulator (PHyLiSS)}

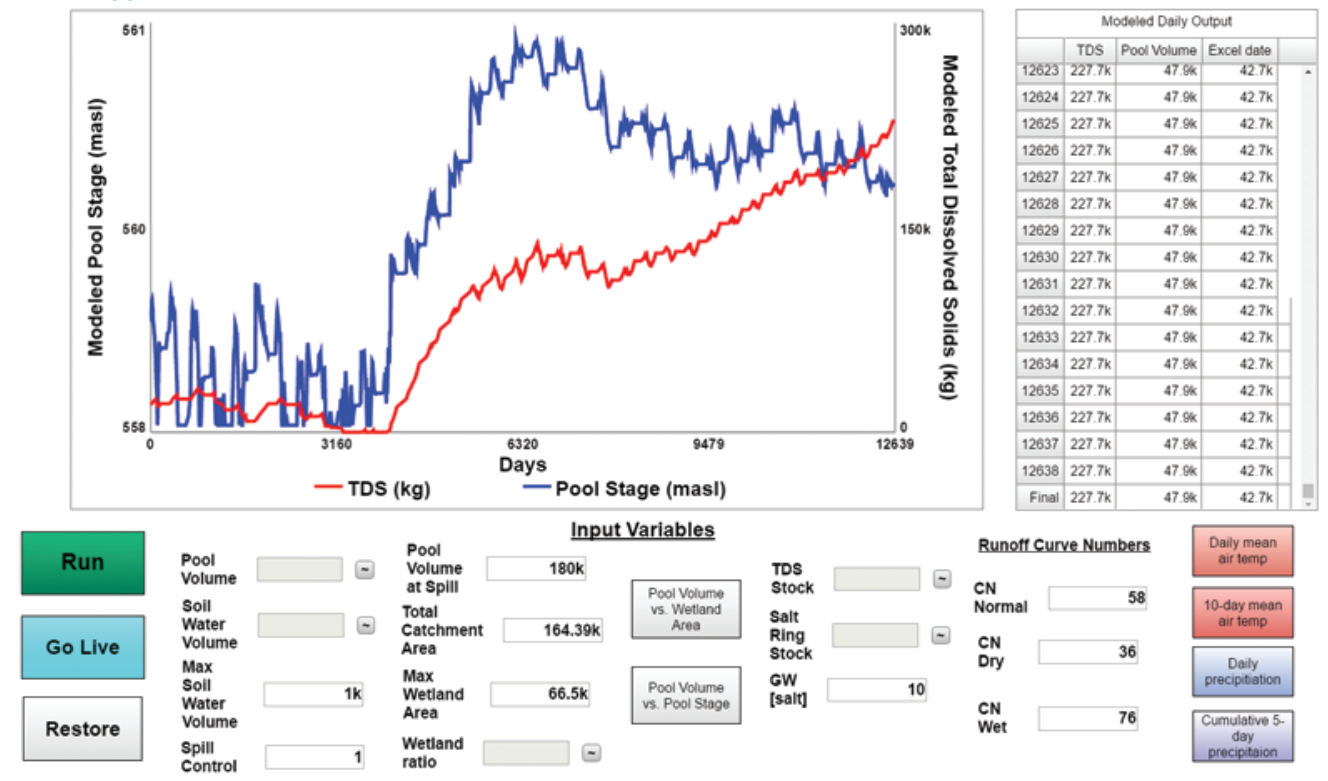

Figure 7. Stella Architect user interface for the Pothole Hydrology-Linked Systems Simulator (PHyLiSS) model. compared to the full version available from ScienceBase. The Stella Architect version of the model is housed on a website that can be openly accessed via a Creative Commons license. This site can be accessed at https://exchange.iseesystems.com/ public/opmckenna/phyliss/index.html\#page1. The default model accessed through the interface is for Cottonwood Lake study area wetland P1 and uses temperature and precipitation data from 1982 to 2015. The output information is downloadable tabular water-volume (in cubic meters) and TDS-mass (in kilograms) data. Users have the option of changing several input parameters to fit their own wetland basin, climate conditions, or both. A more fully functioning version of PHyLiSS accessible through the Stella Architect user interface is in development.

\section{Input Parameters}

Within the Stella Architect user interface, two graphical relation inputs are needed for PHyLiSS to run: the volume to stage ratio and the volume to area ratio. The volume to stage ratio relates the volume of water in the wetland pond to the water surface elevation based on the bathymetry of the wetland. The volume to area ratio relates the volume of water ponded in a wetland to the total area of the water surface. If this second relation is unknown for a study wetland, an empirically derived regional estimate (table 7) can be used instead. When the user selects one of these graphical inputs, they have the option of manually changing the shape of the relation on the graph or changing the points used to generate the curve in the table.

Pool volume (in cubic meters) and soil-water volume (in cubic meters) inputs are needed for the starting point of the model run. Other physical parameters needed are the maximum soil water volume (in cubic meters), wetland pool volume (in cubic meters), and maximum wetland area (in square meters). Catchment information needed includes the total catchment area (in square meters), which includes the wetland area. If the catchment area is not known, an empirically derived regional estimate (table 7) can be used instead. Catchment land cover is incorporated into the Runoff Curve Number, which is represented by the abbreviation " $\mathrm{CN}$ " in the model (table 1). There are three $\mathrm{CNs}$ for a given land-cover type that represent dry, average, and wet moisture conditions. Examples of curve numbers for meadow, grazed pasture, and row crops are given in table 1 . The wetland ratio input variable is needed to calculate snowmelt. Wetland ratio is the maximum wetland area divided by the total catchment area.

Input parameters also are required to incorporate spill of surface water entering a wetland from an adjacent basin. Spill control is used to account for fill-and-spill dynamics. If spill control is 1 , then spill water is incorporated in the wetland water budget. If spill control is 0 , then no spill water is incorporated in the wetland water budget. A spill volume (in cubic meters) for the wetland in the adjacent basin needs to be set as well. If this volume is reached during a model run, then water spills from the wetland in a neighboring basin into the wetland at a lower elevation.

Salinity input variables are the TDS starting stock (in kilograms) and salt-ring starting stock (in kilograms). The user interface also has three buttons on the right side. The first button is the "run" button that starts a model run. The second button is the "go live" button. When this button is selected, the graphical output will respond to changes in the input variables in real time. The third button is the "restore" button that, when selected, restores all input variable information to the default model. 
Table 7. Models developed to estimate wetland volume and upland-zone area by physiographic region in the Prairie Pothole Region adapted from Gleason and Tangen (2008).

\begin{tabular}{llcccc}
\hline Predicted variable & Physiographic region & Number of wetlands & $\begin{array}{c}\text { Mean size, } \\
\text { in hectares }\end{array}$ & $\begin{array}{c}\text { Coefficient of } \\
\text { Modelermination }\left(\boldsymbol{R}^{2}\right)\end{array}$ \\
\hline Wetland volume & Glaciated plains & 288 & 0.92 & $V=0.25 A^{1.4742}$ & 0.91 \\
Wetland volume & Missouri coteau & 186 & 1.28 & $V=0.398 A^{1.542}$ & 0.91 \\
Wetland volume & Prairie coteau & 23 & 2.22 & $V=0.458 A^{1.5611}$ & 0.94 \\
Upland-zone area & Glaciated plains & 288 & 2.19 & $U A=2.24 A^{0.4647}$ & 0.49 \\
Upland-zone area & Missouri coteau & 186 & 2.70 & $U A=2.42 A^{0.5172}$ & 0.62 \\
Upland-zone area & Prairie coteau & 23 & 3.85 & $U A=2.27 A^{0.6603}$ & 0.65 \\
\hline
\end{tabular}

\section{Output Data}

Graphical output and tabular output (fig. 7) can be saved and downloaded from each model run. TDS (in kilograms), pool volume (in cubic meters), and date are available for each time step of the model run. Graphical output includes a figure with two y axes representing modeled pool stage (in cubic meters) and modeled TDS (in kilograms).

\section{Applications and Future Directions}

\section{Continued Model Development}

\section{Geochemical Mechanisms}

We plan to use future empirical and geochemical modeling advances to continue to improve PHyLiSS to better simulate geochemical transformations beyond salinity. Goldhaber and others (2016) demonstrate the capabilities and applications of using thermodynamic-based mass balance modeling techniques to better understand specific phase and redox mass transfers through time. Other studies in the Prairie Pothole Region highlight the potential importance of salt transport during droughts (Levy and others, 2018b) and the biophysical processes incorporated in the development of salt rings (Heagle and others, 2013; Nachshon and others, 2013). Biologically mediated processes such as sulfate reduction have also been extremely abundant in prairie-pothole wetlands (Martins and others, 2017). These important processes may be better represented in future iterations of PHyLiSS.

\section{Expansion Throughout the Prairie Pothole Region}

We plan to develop a network of collaborators across the Prairie Pothole Region to continue to test and validate PHyLiSS. The open-access Stella Architect user interface is a useful resource for collaborators in the United States and
Canada to test the accuracy of PHyLiSS for simulating site-specific wetland hydrology and salinity across the Prairie Pothole Region. Our initial focus will be using PHyLiSS to integrate wetland research at the Cottonwood Lake study area with other long-term research sites such as the St. Denis National Wildlife Area in Saskatchewan (Hayashi and others, 2016) and the Orchid Meadows wetland site in South Dakota (Johnson and Poiani, 2016). We also plan to begin testing PHyLiSS in other depressional-wetland systems outside of the Prairie Pothole Region, for example, playa wetlands of the High Plains.

\section{Climate Change}

We plan to first apply PHyLiSS to address potential effects of climate change to test the use of grazing and burning as a mitigation strategy for these effects on prairie-pothole wetlands. Renton and others (2015) summarize examples of several grazing, burning, and snow management strategies for preserving temporarily inundated prairie-pothole wetlands in the face of rising evapotranspirative demands that are expected in the future. We will simulate climate change by manipulating temperature and precipitation input data to match predictions from the 2014 U.S. National Climate Assessment (Melillo and others, 2014). Grazing and burning management practices will be independently simulated by manipulating the runoff $\mathrm{CN}$ inputs to match those in the literature.

We also plan to use PHyLiSS to improve on current region-scale projections of the effect that climate change will have on the future suitability of waterfowl habitat in the Prairie Pothole Region. Results of this work will provide U.S. Fish and Wildlife Service land managers with information needed to make more informed decisions about where to invest limited financial and labor resources to better ensure sustainability of waterfowl populations. Our work will differ from past climate-change modeling of prairie-pothole wetlands in three ways. First, the PHyLiSS model is designed to fit any given wetland area and catchment size. Rather than applying different climate-change manipulations on the same wetland complex, we will be able to parameterize the model using region-specific wetland and catchment morphology data from Gleason and Tangen (2008). Second, we will use intra-annual 
changes in precipitation as reported in the 2014 U.S. National Climate Assessment (Melillo and others, 2014). Previous efforts only manipulated precipitation equally throughout the year. Lastly, the PHyLiSS model will be able to simulate wetland salinity in addition to wetland hydroperiod. This will provide a more accurate way to estimate wetland habitat suitability for all wetlands rather than simulated vegetation dynamics for only semipermanent wetlands.

\section{Land-Use Change}

More than 90 percent of the original grasslands and wetlands have now been converted to farmlands in the Northern Great Plains region (Wright and Wimberly, 2013). From 2005 to 2007 alone, more than 3.2 million new acres were planted to corn in Prairie Pothole Region areas of Iowa, Minnesota, North Dakota, and South Dakota (Gascoigne and others, 2013). We plan to use the capabilities of PHyLiSS to address the direct effects of land-use change on prairie-pothole wetlands and how wetlands will be affected by the joint effects of climate and land-use change.

\section{Integrated Landscape Modeling Partnership}

Once we can simulate the hydrology, chemistry, and biology of prairie-pothole wetlands, we can apply PHyLiSS to land-management planning and the quantification of ecosystem services. We are planning on using information gained from these modeling efforts to inform Integrated Landscape Modeling efforts throughout the Prairie Pothole Region (Mushet and Scherff, 2016). Expanded applications of PHyLiSS will create an opportunity for this tool to contribute to assessments of the effects of conservation programs and practices on prairie-pothole wetlands and the ecosystem services that accompany those wetlands (Mushet and Scherff, 2016) in addition to providing information needed by land managers and policymakers across the Prairie Pothole Region.

\section{Summary}

The Pothole Hydrology-Linked Systems Simulator (PHyLiSS) is a systems model for exploring the effects of climate and land-use change on prairie-pothole wetland ecosystems. Early development for PHyLiSS was funded by the U.S. Department of Agriculture Conservation Effects and Assessment Project (Wetlands). Under the U.S. Geological Survey Climate Research and Development Program, we refined and expanded PHyLiSS to the model's current state. The hydrological and geochemical components of PHyLiSS have been calibrated and validated using empirical data from six prairie-pothole wetlands within the Cottonwood Lake study area. The biological components of PHyLiSS are currently being developed. In this report, we provide users with the theoretical background, instructions, and examples of how the PHyLiSS model can be used to inform land management decisions across the Prairie Pothole Region.

\section{References Cited}

Ballard, T., Seager, R., Smerdon, J.E., Cook, B.I., Ray, A.J., Rajagopalan, B., Kushnir, Y., Nakamura, J., and Henderson, N., 2014, Hydroclimate variability and change in the Prairie Pothole Region, the "duck factory" of North America: Earth Interactions, v. 18, p. 1-28. [Also available at https://doi. org/10.1175/EI-D-14-0004.1.]

Batt, B., Anderson, M., Anderson, C., and Caswell, F., 1989, Use of prairie potholes by North American ducks, in Van Der Valk, A., ed., Northern prairie wetlands: Ames, Iowa, Iowa State University Press, p. 204-227.

Blann, K.L., Anderson, J.L., Sands, G.R., and Vondracek, B., 2009, Effects of agricultural drainage on aquatic ecosystems-A review: Critical Reviews in Environmental Science and Technology, v. 39, no. 11, p. 909-1001. [Also available at https://doi.org/10.1080/10643380801977966.]

Costanza, R., and Voinov, A., 2001, Modeling ecological and economic systems with STELLA-Part III: Ecological Modelling, v. 143, nos. 1-2, p. 1-7. [Also available at https://doi.org/10.1016/S0304-3800(01)00358-1.]

Cox, R.R., Jr., Hanson, M.A., Roy, C.C., Euliss, N.H., Jr., Johnson, D.H., and Butler, M.G., 1998, Mallard duckling growth and survival in relation to aquatic invertebrates: The Journal of Wildlife Management, v. 62, no. 1, p. 124-133. [Also available at https://doi.org/10.2307/3802270.]

Cronshey, R., McCuen, R.H., Miller, N., Rawls, W., Robbins, S., and Woodward, D., 1986, Urban hydrology for small watersheds: U.S. Department of Agriculture, Technical Release 55 [variously paged].

Dumanski, S., Pomeroy, J.W., and Westbrook, C.J., 2015, Hydrological regime changes in a Canadian Prairie Basin: Hydrological Processes, v. 29, no. 18, p. 3893-3904. [Also available at https://doi.org/10.1002/hyp.10567.]

Dyke, A., and Prest, V., 1987, Late Wisconsinan and Holocene history of the Laurentide Ice Sheet: Géographie physique et Quaternaire, v. 41, no. 2, p. 237-264. [Also available at https://doi.org/10.7202/032681ar.]

Euliss, N.H., Labaugh, J.W., Fredrickson, L.H., Mushet, D.M., Laubhan, M.K., Swanson, G.A., Winter, T.C., Rosenberry, D.O., and Nelson, R.D., 2004, The wetland continuum-A conceptual framework for interpreting biological studies: Wetlands, v. 24, no. 2, p. 448-458. [Also available at https:// doi.org/10.1672/0277-5212(2004)024[0448:TWCACF]2.0 .CO;2.] 
Fang, X., and Pomeroy, J.W., 2007, Snowmelt runoff sensitivity analysis to drought on the Canadian prairies: Hydrological Processes, v. 21, no. 19, p. 2594-2609. [Also available at https://doi.org/10.1002/hyp.6796.]

Gascoigne, W.R., Hoag, D.L.K., Johnson, R.R., and Koontz, L.M., 2013, Dynamics of land-use change and conservation in the Prairie Pothole Region of the United States-Environmental and economic implications with linkages to rural community well-being (rev. July 19, 2013): U.S. Geological Survey Professional Paper 1800, 65 p. [Also available at https://pubs.usgs.gov/pp/1800/.]

Gleason, R.A., and Tangen, B.A., 2008, Floodwater storage, chap. D of Gleason, R.A., Laubhan, M.K., and Euliss, N.H., Jr., eds., Ecosystem services derived from wetland conservation practices in the United States Prairie Pothole Region with emphasis on the U.S. Department of Agriculture Conservation Reserve and Wetlands Reserve Programs: U.S. Geological Survey Professional Paper 1745, p. 31-37. [Also available at https://pubs.usgs.gov/pp/1745/.]

Goldhaber, M.B., Mills, C.T., Stricker, C.A., and Morrison, J.M., 2011, The role of critical zone processes in the evolution of the Prairie Pothole Region wetlands: Applied Geochemistry, v. 26, p. S32-S35. [Also available at https:// doi.org/10.1016/j.apgeochem.2011.03.022.]

Goldhaber, M.B., Mills, C.T., Morrison, J.M., Stricker, C.A., Mushet, D.M., and LaBaugh, J.W., 2014, Hydrogeochemistry of Prairie Pothole Region wetlands-Role of longterm critical zone processes: Chemical Geology, v. 387, p. 170-183. [Also available at https://doi.org/10.1016/j. chemgeo.2014.08.023.]

Goldhaber, M.B., Mills, C.T., Mushet, D.M., McCleskey, R.B., and Rover, J., 2016, Controls on the geochemical evolution of Prairie Pothole Region lakes and wetlands over decadal time scales: Wetlands, v. 36, no. S2, p. 255-272. [Also available at https://doi.org/10.1007/s13157-016-08544.]

Hamon, W.R., 1961, Estimating potential evapotranspiration: Journal of the Hydraulics Division, v. 87, p. 107-120.

Hayashi, M., van der Kamp, G., and Rudolph, D.L., 1998, Water and solute transfer between a prairie wetland and adjacent uplands, 1. water balance: Journal of Hydrology, v. 207, nos. 1-2, p. 42-55. [Also available at https://doi. org/10.1016/S0022-1694(98)00098-5.]

Hayashi, M., van der Kamp, G., and Rosenberry, D.O., 2016, Hydrology of prairie wetlands-Understanding the integrated surface-water and groundwater processes: Wetlands, v. 36, no. S2, p. 237-254. [Also available at https://doi. org/10.1007/s13157-016-0797-9.]
Heagle, D., Hayashi, M., and van der Kamp, G., 2013, Surface-subsurface salinity distribution and exchange in a closed-basin prairie wetland: Journal of Hydrology, v. 478, p. 1-14. [Also available at https://doi.org/10.1016/j.jhydrol.2012.05.054.]

Huang, S., Young, C., Abdul-Aziz, O.I., Dahal, D., Feng, M., and Liu, S., 2013, Simulating the water budget of a Prairie Potholes complex from LiDAR and hydrological models in North Dakota, USA: Hydrological Sciences Journal, v. 58, no. 7, p. 1434-1444. [Also available at https://doi.org/10.10 80/02626667.2013.831419.]

Johnson, W.C., Werner, B., and Guntenspergen, G.R., 2016, Non-linear responses of glaciated prairie wetlands to climate warming: Climatic Change, v. 134, nos. 1-2, p. 209223. [Also available at https://doi.org/10.1007/s10584-0151534-8.]

Johnson, W.C., Millett, B.V., Gilmanov, T., Voldseth, R.A., Guntenspergen, G.R., and Naugle, D.E., 2005, Vulnerability of northern prairie wetlands to climate change: Bioscience, v. 55, no. 10, p. 863-872. [Also available at https:// doi.org/10.1641/0006-3568(2005)055[0863:VONPWT]2.0 .CO;2.]

Johnson, W.C., Werner, B., Guntenspergen, G.R., Voldseth, R.A., Millett, B., Naugle, D.E., Tulbure, M., Carroll, R.W.H., Tracy, J., and Olawsky, C., 2010, Prairie wetland complexes as landscape functional units in a changing climate: Bioscience, v. 60 , no. 2, p. 128-140. [Also available at https://doi.org/10.1525/bio.2010.60.2.7.]

Johnson, W.C., and Poiani, K.A., 2016, Climate change effects on Prairie Pothole wetlands-Findings from a twenty-five year numerical modeling project: Wetlands, v. 36, no. S2, p. 273-285. [Also available at https://doi.org/10.1007/ s13157-016-0790-3.]

Johnston, C.A., 2013, Wetland losses due to row crop expansion in the Dakota Prairie Pothole Region: Wetlands, v. 33, no. 1, p. 175-182. [Also available at https://doi.org/10.1007/ s13157-012-0365-x.]

Kantrud, H.A., Krapu, G.L., and Swanson, G.A., 1989, Prairie basin wetlands of the Dakotas-A community profile: Washington, D.C., U.S. Department of the Interior, Fish and Wildlife Service, Research and Development, Biological Report, v. 85, no. 7.28, 116 p. [Also available at https:// www.nwrc.usgs.gov/techrpt/85-7-28.pdf.]

LaBaugh, J.W., Winter, T.C., Swanson, G.A., Rosenberry, D.O., Nelson, R.D., and Euliss, N.H., Jr., 1996, Changes in atmospheric circulation patterns affect midcontinent wetlands sensitive to climate: Limnology and Oceanography, v. 41 , no. 5, p. 864-870. [Also available at https://doi. org/10.4319/lo.1996.41.5.0864.] 
LaBaugh, J.W., Mushet, D.M., Rosenberry, D.O., Euliss, N.H., Jr., Goldhaber, M.B., Mills, C.T., and Nelson, R.D., 2016, Changes in pond water levels and surface extent due to climate variability alter solute sources to closed-basin Prairie-Pothole wetland ponds, 1979 to 2012: Wetlands, v. 36, no. S2, p. 343-355. [Also available at https://doi. org/10.1007/s13157-016-0808-x.]

LaBaugh, J.W., Rosenberry, D.O., Mushet, D.M., Neff, B.P., Nelson, R.D., and Euliss, N.H., Jr., 2018, Long-term changes in pond permanence, size, and salinity in Prairie Pothole Region wetlands-The role of groundwater-pond interaction: Journal of Hydrology — Regional Studies, v. 17, p. 1-23. [Also available at https://doi.org/10.1016/j. ejrh.2018.03.003.]

Leibowitz, S.G., Mushet, D.M., and Newton, W.E., 2016, Intermittent surface water connectivity-Fill and spill vs. fill and merge dynamics: Wetlands, v. 36, no. 2, p. 323-342. [Also available at https://doi.org/10.1007/s13157-0160830-z.]

Levy, Z.F., Mills, C.T., Lu, Z., Goldhaber, M.B., Rosenberry, D.O., Mushet, D.M., Lautz, L.K., Zhou, X., and Siegel, D.I., 2018b, Using halogens (Cl, Br, I) to understand the hydrogeochemical evolution of drought-derived saline porewater beneath a prairie wetland: Chemical Geology, v. 476, p. 191-207. [Also available at https://doi.org/10.1016/j. chemgeo.2017.11.017.]

Levy, Z.F., Rosenberry, D.O., Moucha, R., Mushet, D.M., Goldhaber, M.B., LaBaugh, J.W., Fiorentino, A.J., and Siegel, D.I., 2018a, Drought-induced recharge promotes longterm storage of porewater salinity beneath a prairie wetland: Journal of Hydrology, v. 557, p. 391-406. [Also available at https://doi.org/10.1016/j.jhydrol.2017.12.005.]

Martins, P.D., Hoyt, D.W., Bansal, S., Mills, C.T., Tfaily, M., Tangen, B.A., Finocchiaro, R.G., Johnston, M.D., McAdams, B.C., Solensky, M.J., Smith, G.J., Chin, Y., and Wilkins, M.J., 2017, Abundant carbon substrates drive extremely high sulfate reduction rates and methane fluxes in prairie pothole wetlands: Global Change Biology, v. 23, no. 8, p. 3107-3120. [Also available at https://doi. $\operatorname{org} / 10.1111 / \mathrm{gcb} .13633$.

McCauley, L.A., Anteau, M.J., Post van der Burg, M., and Wiltermuth, M.T., 2015, Land use and wetland drainage affect water levels and dynamics of remaining wetlands: Ecosphere, v. 6, no. 6, p. 1-22. [Also available at https://doi. org/10.1890/ES14-00494.1.]

McKenna, O.P., Mushet, D.M., Rosenberry, D.O., and LaBaugh, J.W., 2017, Evidence for a climate-induced ecohydrological state shift in wetland ecosystems of the southern Prairie Pothole Region: Climatic Change, v. 145, nos. 3-4, p. 273-287. [Also available at https://doi. org/10.1007/s10584-017-2097-7.]
McLean, K.I., Mushet, D.M., Renton, D.A., and Stockwell, C.A., 2016a, Aquatic-macroinvertebrate communities of prairie-pothole wetlands and lakes under a changed climate: Wetlands, v. 36, no. S2, p. 423-435. [Also available at https://doi.org/10.1007/s13157-016-0848-2.]

McLean, K.I., Mushet, D.M., and Stockwell, C.A., 2016b, From "duck factory" to "fish factory"-Climate induced changes in vertebrate communities of prairie pothole wetlands and small lakes: Wetlands, v. 36, no. S2, p. 407-421. [Also available at https://doi.org/10.1007/s13157-016-07663.]

Melillo, J.M., Richmond, T.T., and Yohe, G., 2014, Climate change impacts in the United States-The third national climate assessment: U.S. Global Change Research Program, $841 \mathrm{p}$. [Also available at https://doi.org/10.7930/ J0Z31WJ2.]

Mushet, D.M., 2016, Midcontinent prairie-pothole wetlands and climate change - An introduction to the supplemental issue: Wetlands, v. 36, no. S2, p. 223-228. [Also available at https://doi.org/10.1007/s13157-016-0852-6.]

Mushet, D.M., Christensen, J.R., Bennett, M., and Alexander, L.C., 2017, Biota-Providing often-overlooked connections among freshwater systems: Water Resources Impact, v. 19, no. 2, p. 11-13.

Mushet, D.M., Goldhaber, M.B., Mills, C.T., McLean, K.I., Aparicio, V.M., McCleskey, R.B., Holloway, J.M., and Stockwell, C.A., 2015, Chemical and biotic characteristics of prairie lakes and large wetlands in south-central North Dakota—Effects of a changing climate: U.S. Geological Survey Scientific Investigations Report 2015-5126, 55 p. [Also available at https://doi.org/10.3133/sir20155126.]

Mushet, D.M., McKenna, O.P., LaBaugh, J.W., Euliss, N.H., Jr., and Rosenberry, D.O., 2018, Accommodating state shifts within the conceptual framework of the wetland continuum: Wetlands, v. 38, no. 3, p. 647-651. [Also available at https:// doi.org/10.1007/s13157-018-1004-y.]

Mushet, D.M., and Scherff, E.J., 2016, The Integrated Landscape Modeling partnership-Current status and future directions (ver. 1.1, December 2016): U.S. Geological Survey Open-File Report 2016-1006, 59 p. [Also available at https://doi.org/10.3133/ofr20161006.]

Nachshon, U., Ireson, A., van der Kamp, G., and Wheater, H., 2013, Sulfate salt dynamics in the glaciated plains of North America: Journal of Hydrology, v. 499, p. 188-199. [Also available at https://doi.org/10.1016/j.jhydrol.2013.07.001.]

Poiani, K.A., and Johnson, W.C., 1993, A spatial simulation model of hydrology and vegetation dynamics in semi-permanent prairie wetlands: Ecological Applications, v. 3, no. 2, p. 279-293. [Also available at https://doi. org/10.2307/1941831.] 
Poiani, K.A., Johnson, W.C., Swanson, G.A., and Winter, T.C., 1996, Climate change and northern prairie wetlands-Simulations of long-term dynamics: Limnology and Oceanography, v. 41, no. 5, p. 871-881. [Also available at https://doi. org/10.4319/1o.1996.41.5.0871.]

Post van der Burg, M., Anteau, M.J., McCauley, L.A., and Wiltermuth, M.T., 2016, A Bayesian approach for temporally scaling climate for modeling ecological systems: Ecology and Evolution, v. 6, no. 9, p. 2978-2987. [Also available at https://doi.org/10.1002/ece3.2092.]

Rehm, B.W., Moran, S.R., and Groenewold, G.H., 1982, Natural groundwater recharge in an upland area of central North Dakota, U.S.A: Journal of Hydrology, v. 59, nos. 3-4, p. 293-314. [Also available at https://doi.org/10.1016/00221694(82)90093-2.]

Renton, D.A., Mushet, D.M., and DeKeyser, E.S., 2015, Climate change and prairie pothole wetlands-Mitigating water-level and hydroperiod effects through upland management: U.S. Geological Survey Scientific Investigations Report 2015-5004, 21 p. [Also available at https://doi. org/10.3133/sir20155004.]

Rosenberry, D.O., and Winter, T.C., 1997, Dynamics of water-table fluctuations in an upland between two prairiepothole wetlands in North Dakota: Journal of Hydrology, v. 191, nos. 1-4, p. 266-289. [Also available at https://doi. org/10.1016/S0022-1694(96)03050-8.]

Rosenberry, D.O., 2003, Climate of the Cottonwood Lake area, chap. 2 of of Winter, T.C., ed., Hydrological, chemical, and biological characteristics of a prairie pothole wetland complex under highly variable climate conditionsThe Cottonwood Lake area, east-central North Dakota: U.S. Geological Survey Professional Paper 1675, p. 25-34. [Also available at https://doi.org/10.3133/pp1675.]

Rosenberry, D.O., Stannard, D.I., Winter, T.C., and Martinez, M.L., 2004, Comparison of 13 equations for determining evapotranspiration from a prairie wetland, Cottonwood Lake area, North Dakota, USA: Wetlands, v. 24, no. 3, p. 483-497. [Also available at https://doi.org/10.1672/02775212(2004)024[0483:COEFDE]2.0.CO;2.]

Ryberg, K.R., Lin, W., and Vecchia, A.V., 2014, Impact of climate variability on runoff in the north-central United States: Journal of Hydrologic Engineering, v. 19, no. 1, p. 148-158. [Also available at https://doi.org/10.1061/(ASCE)HE.19435584.0000775.]

Shook, K., and Pomeroy, J., 2012, Changes in the hydrological character of rainfall on the Canadian prairies: Hydrological Processes, v. 26, no. 12, p. 1752-1766. [Also available at https://doi.org/10.1002/hyp.9383.]
Smith, A., Stoudt, J., and Gallop, J., 1964, Prairie pothole wetlands and marshes, in Linduska, J.P., ed., Waterfowl tomorrow: Washington, D.C., U.S. Department of Interior, p. $39-50$.

Steen, V.A., Skagen, S.K., and Melcher, C.P., 2016, Implications of climate change for wetland-dependent birds in the Prairie Pothole Region: Wetlands, v. 36, no. S2, p. 445-459. [Also available at https://doi.org/10.1007/s13157-016-07912.]

Todhunter, P.E., and Fietzek-DeVries, R., 2016, Natural hydroclimatic forcing of historical lake volume fluctuations at Devils Lake, North Dakota (USA): Natural Hazards, v. 81, no. 3, p. 1515-1532. [Also available at https://doi. org/10.1007/s11069-015-2143-6.]

van der Kamp, G., and Hayashi, M., 2009, Groundwater-wetland ecosystem interaction in the semiarid glaciated plains of North America: Hydrogeology Journal, v. 17, no. 1, p. 203-214. [Also available at https://doi.org/10.1007/ s10040-008-0367-1.]

Winter, T.C., and Rosenberry, D.O., 1995, The interaction of ground water with prairie pothole wetlands in the Cottonwood Lake area, east-central North Dakota, 1979-1990: Wetlands, v. 15, no. 3, p. 193-211. [Also available at https:// doi.org/10.1007/BF03160700.]

Winter, T.C., and Rosenberry, D.O., 1998, Hydrology of prairie pothole wetlands during drought and deluge-A 17-year study of the cottonwood lake wetland complex in North Dakota in the perspective of longer term measured and proxy hydrological records: Climatic Change, v. 40, no. 2, p. 189-209. [Also available at https://doi. org/10.1023/A:1005448416571.]

Winter, T.C., 2003, Hydrological, chemical, and biological characteristics of a prairie pothole wetland complex under highly variable climate conditions - The Cottonwood Lake area, east-central North Dakota: U.S. Geological Survey Professional Paper 1675, 109 p. [Also available at https:// doi.org/10.3133/pp1675.]

Wright, C.K., and Wimberly, M.C., 2013, Recent land use change in the western Corn Belt threatens grasslands and wetlands: Proceedings of the National Academy of Sciences of the United States of America, v. 110, no. 10, p. 4134-4139. [Also available at https://doi.org/10.1073/ pnas.1215404110.] 
For more information about this publication, contact:

Director, USGS Northern Prairie Wildlife Research Center 8711 37th Street Southeast

Jamestown, ND 58401

701-253-5500

For additional information, visit: https://www.usgs.gov/centers/npwrc

Publishing support provided by the

Rolla Publishing Service Center 



\section{鄫}

3

종 